RESEARCH SEMINAR IN INTERNATIONAL ECONOMICS

Gerald R. Ford School of Public Policy

The University of Michigan

Ann Arbor, Michigan 48109-3091

Discussion Paper No. 620

\title{
The Impact of Foreign Liabilities on Small Firms: Firm-Level Evidence from the Korean Crisis
}

\author{
Yun Jung Kim \\ University of Michigan \\ Linda L. Tesar \\ University of Michigan and NBER \\ Jing Zhang \\ University of Michigan
}

December 12, 2011

Recent RSIE Discussion Papers are available on the World Wide Web at: http://www.fordschool.umich.edu/rsie/workingpapers/wp.html 


\title{
THE IMPACT OF Foreign Liabilities ON SMALl Firms: Firm-LEVEL EVIDENCE FROM THE KOREAN CRISIs*
}

\author{
Yun Jung Kim \\ University of Michigan
}

\author{
Linda L. Tesar \\ University of Michigan \\ and NBER
}

\author{
Jing Zhang ${ }^{* *}$ \\ University of Michigan
}

December 12, 2011

\begin{abstract}
Using Korean firm-level data on publicly-listed and privately-held firms together with firm exit data, we find strong evidence of the balance-sheet effect for small firms at both the intensive and extensive margins. During the crisis, small firms with more short-term foreign debt are more likely to go bankrupt, and experience larger sales declines conditional on survival. The extensive margin accounts for a large fraction of small firms' adjustment during the crisis. Consistent with many studies in the literature, large firms with larger exposure to foreign debt paradoxically have better performance during the crisis at both the intensive and extensive margin.
\end{abstract}

\section{JEL: F32 F34 E44}

Keywords: financial crisis, firm-level data, balance-sheet effects, Korean economy

\footnotetext{
* The authors would like to thank Chris House, Andrei Levchenko, Kathryn Dominguez, Amy Dittmar, and participants of seminars at the University of Michigan and the Australian National University.

** Correspondence: Kim: yunjungk@umich.edu; Tesar: ltesar@,umich.edu; Zhang: jzhang@umich.edu.
} 


\section{Introduction}

The sequence of events experienced by an emerging market undergoing a financial crisis is now all-too-familiar. Rapid economic growth and financial market liberalization encourage capital inflow, contributing to an overvalued exchange rate and increased reliance on foreign credit, usually denominated in US dollars. As economic growth and exports slow, the economy tips into a crisis. The exchange rate collapses, capital flow reverses and firms find themselves unable to meet their debt requirements. Firms, and in some cases governments, become insolvent. Those deemed "too big to fail" may receive bailouts; others slash employment, declare bankruptcy or are sold to foreign owners.

While the general anatomy of crises has been well documented, ${ }^{1}$ the exact channels through which a financial crisis translates into a real economic contraction at the microeconomic level are less well understood. Traditional macroeconomic models predict that a depreciation of the exchange rate will be expansionary by making exports more competitive. However, if the depreciation occurs when firms are holding significant foreign-currency denominated liabilities, a negative balance-sheet effect may outweigh the export-expansion effect (Krugman 1999, Céspedes, Chang and Velasco 2004, and Feldstein 1999). In general, the literature has found ample evidence of the export-expansion effect but limited evidence of the balance-sheet effect. $^{2}$ Due to data limitations, most existing firm-level studies examine only publicly-listed firms that survived the financial crisis, and leave the extensive margin of the balance-sheet effect unexplored.

In this paper, we use a detailed database on over 4,000 Korean firms-both privately-held and publicly-listed—-to study the impact of the 1997-1998 Korean fi-

\footnotetext{
${ }^{1}$ See for example Corsetti et. al. (1998).

2 Benavente et. al. (2003), Bleakley and Cowan (2008), Bonomo et.al. (2003), Forbes (2002), and Luengnaruenitchai (2003) find either a positive balance-sheet effect or no balance-sheet effect. In contrast, Aguiar (2005), Carranza et. al. (2003), Echeverrya et. al. (2003), Gilchrist and Sim (2007) and Pratapa et.al. (2003) find some evidence of a negative balance-sheet effect.
} 
nancial crisis on firm performance. The database contains information on firms' export status, holdings of foreign debt, and total indebtedness along with a host of other firm-level characteristics. The database also provides information about firm exit during the crisis. We exploit the heterogeneity across firms to see which factors-firm size, industry, export status, exposure to foreign debt, and term structure of debt-are critical for explaining firm performance and firm exit leading up to and during the Korean crisis.

Our analysis yields three key findings. First, we find evidence of a significantly negative balance-sheet effect for small firms conditional on survival. Specifically, for a firm at the $10^{\text {th }}$ percentile of the size distribution (with size measured by real assets), a one percent increase in its short-term foreign debt ratio prior to the crisis is associated with a 0.31 percent lower rate of sales growth during the crisis. Most existing firm-level studies focus on publicly-listed firms and often find either no balance-sheet effect or a positive balance-sheet effect. The reason we are able to find evidence of a significantly negative balance-sheet effect is because of the broad coverage of our dataset, which includes both well-established, publicly-listed firms as well as small, privately-held firms. This balance-sheet effect becomes insignificant when one focuses only on publicly-listed firms as in previous studies. Publicly-listed firms tend to be larger, are more likely to be exporting firms and are more likely to survive the crisis than an average Korean firm.

Second, we find strong evidence of the balance-sheet effect on small firms at the extensive margin: foreign debt holdings are a significant predicator for small firms' exit during the crisis. Consider a percentage point increase in the pre-crisis foreign debt ratio for firms at varying sizes. ${ }^{3}$ The marginal impact on the probability of exit increases from about zero for a firm of median size to 0.28 percentage points for a firm at the $10^{\text {th }}$ percentile. Again, the impact of the crisis on firm exit is missed

\footnotetext{
3 Specifically, the ratio of foreign debt holdings to liabilities is set at the mean level conditional on having foreign debt, and all other characteristics are set at the sample mean.
} 
in samples that focus on publicly-listed firms that survived the 1997-98 contraction. Our dataset makes it possible to study firm exit during the Korean crisis, which accounts for nearly 20 percent of the decline in aggregate sales in the peak year of the crisis. Analysis of exit rates underscores the devastating impact of the crisis on small firms that had foreign liabilities prior to the crisis.

Third, we find a strong export-expansion effect: exporters experience smaller declines in sales growth during the crisis than non-exporters. While in principle exports provide a natural hedge against the negative effects of an exchange rate depreciation, many firms do not export and therefore do not benefit from this channel. Our data suggest that about 70 percent of Korean firms that carried foreign currency debt on their balance sheets at the time of the crisis were not engaged in exporting. Moreover, for the smallest quartile of firms, 90 percent of firms with foreign debt holdings were non-exporters. Therefore, a significant fraction of the population of Korean firms-importantly, many small firms-entered the crisis with exposure to balance-sheet risk with no offsetting benefits of an improvement in global competitiveness.

Paradoxically, we find that large firms with more exposure to foreign debt experience smaller declines in sales growth during the crisis. Similar results have been documented by many studies in the literature focusing on large and publicly-listed firms. We also find that large firms with more exposure to foreign debt are less likely to exit during the crisis. The exact interpretation of these findings is unclear. We suspect that omitted variable bias may be the reason behind these findings. Large firms, like publicly-listed firms, are more likely to hedge exchange rate risk and have access to other means of financing during the crisis. Omitted variable bias may be less severe for small firms than for large firms, so we are able to find evidence of the balance-sheet effect for small firms.

We perform counterfactual exercises to illustrate the importance of these various channels (the balance-sheet effect and the export-expansion effect), taking 
into account both the contraction in sales as well as firm exit. These exercises demonstrate the importance of firm heterogeneity in assessing the role of foreign debt in the crisis. ${ }^{4}$ For large firms, an increase in the foreign debt ratio has very little impact, if any, on firm performance. Similarly, the predicted exit rate changes very little as large firms tend to be hedged through exports. For the bottom quarter of firms, however, an across the board increase in foreign debt predicts a 1.6 percentage point decline in total sales growth conditional on survival. Their predicted exit rate increases by 7.4 percentage points, and the overall predicted decline in sales growthtaking into account sales contraction and firm exit-is nearly 8 percentage points. About 80 percent of the decline in sales growth is explained by firm exit for these small firms. What these experiments suggest is that in assessing exposure to exchange rate risk, it is important to know which firms are carrying foreign currency liabilities and whether those firms are also exporting firms.

The paper is organized as follows. Section 1 briefly presents macroeconomic dynamics of the Korean financial crisis. Section 2 describes the dataset. Section 3 focuses on the surviving firms and presents the evidence of the balance-sheet effect from the cross-sectional regression analysis. Section 4 focuses on the exit margin and documents the balance-sheet effect on firm exit during the financial crisis. We also conduct counterfactual experiments in this section. Section 5 concludes.

\section{Macroeconomic Dynamics of the Korean Financial Crisis}

In the years preceding the Asian financial crisis, South Korea was one of the fastest growing economies in the world, with sustained high growth rates for more than two decades. Beginning in late 1997, the Korean economy entered a severe economic contraction. Some indicators of the magnitude of the crisis are illustrated in Figure 1a, which shows real GDP, consumption, investment and total employment normal-

\footnotetext{
${ }^{4}$ In this counterfactual experiment, we increase firm leverage by ten percentage points and assume that all of the increase is in short-term foreign debt.
} 
ized to their 1997 values. ${ }^{5}$ The declines were big: from peak to trough real GDP declined $7 \%$, real consumption fell 14\%, real investment fell $35 \%$, and employment dropped 5\%. During the crisis, the current account displayed a sudden reversal of over 15 percentage points, shifting from a negative balance of 4\% of GDP to a positive $12 \%$ of GDP (Figure 1b). While the crisis was deep, it was also mercifully brief. By 1999 real GDP and consumption returned to levels above their pre-crisis values.

During the boom years, Korean firms and households dramatically increased their reliance on credit. Between 1995 and 1997, total private credit as a share of GDP increased from 104 percent of GDP to almost 120 percent of GDP (see Figure 1d). Much of the credit expansion took the form of borrowing from abroad. Figure 1c shows that external debt peaked in 1997 at 60 percent of GDP, with over a third of total borrowing with maturities of one year or less. The declines in both total private credit and external debt as shares of GDP in 1997 to 2000 illustrate the dramatic deleveraging that occurred in Korea in the aftermath of the crisis.

Figures 1e and 1f show the dynamics of two key prices: the nominal exchange rate (Korean won relative to the US dollar) and the nominal interest rate (the monthly money market rate). As shown in Figure 1e the nominal exchange rate depreciated by almost 100\% during the last weeks of 1997, peaking in January 1998. Thereafter, the won fully floated against the dollar. It appears that there was significant overshooting of the Korean won-between late-1997 and mid-1998 the won appreciated relative to the dollar although it did not return to its pre-crisis level. The short-term interest rate (Figure 1f) also shot up during the crisis, increasing from its pre-crisis range of 10-15 percent to a peak of 25.6 percent in January 1998.

The severity of the crisis has been attributed to high rates of leverage in the economy, particularly in the form of external debt, coupled with a sudden, unanticipated (and therefore unhedged) exchange rate depreciation. Despite the large literature on this topic, there has been little microeconomic evidence to support the con-

\footnotetext{
5 The plot shows annualized data — the crisis hit in the fourth quarter of 1997.
} 
nection between financial variables and real economic activity. We next describe the firm-level data that we will use to analyze the linkages between balance-sheet risk and firm performance.

\section{Description of Firm-Level Data}

We obtain firm-level data from the Korea Information Service, Inc. (KIS), a provider of financial and corporate data for Korean firms. The underlying source of the data is the annual financial statements of all Korean firms with assets over 7 billion won. ${ }^{6}$ The KIS removes liquidated firms from the dataset, and therefore the main dataset contains only surviving firms. We obtained additional information on liquidated firms from the KIS in a secondary database. ${ }^{7}$

The KIS data have several advantages over the data that have been employed in earlier studies of financial crises in emerging markets. ${ }^{8}$ First, the KIS data include firms that are not listed on the Korean stock exchange. The KIS data reveal that publicly-listed firms are only a fraction of the population of Korean firms and they provide a skewed portrait of the impact of the crisis at the micro-level. The KIS data also provide information on foreign currency denominated debt versus domestic debt $^{9}$ as well as the maturity structure of the debt. The database contains firm-level information on whether a firm is an exporter or not, allowing us to disentangle the

${ }^{6}$ Firms with assets of 7 billion won or more are required by the Act on External Audit of Joint-Stock Corporations to report audited financial statements to the Financial Supervisory Commission, which is then compiled by the KIS. Some firms with assets less than 7 billion won voluntarily report their financial statements and show up in the dataset.

${ }^{7}$ Data on liquidated firms were available by special request from the KIS.

${ }^{8}$ Examples, among many others, include Aguiar (2005), Bleakley and Cowan (2008), Borensztein and Lee (2002), Forbes (2002), Gilchrist and Sim (2007), Kalemli-Ozcan et al (2009), and Martinez and Werner (2002). All these papers focus on publicly listed firms. Bleakley and Cowan (2008) have no information on export status and Forbes (2002) uses total debt statistics instead of foreign debt. All these papers, except Kalemli-Ozcan et al (2009), have no exit information. In Kalemli-Ozcan et al (2009) firms rarely exit, so the extensive margin plays a limited role in their study.

9 The KIS does not provide the currency denomination of foreign debt. However, other sources indicate that the majority of foreign borrowing was denominated in US dollars. According to Kwon (2005), prior to the crisis 96 percent of foreign debt of publicly-listed firms was in US dollars, 3 percent in yen, and 1 percent in other currencies. 
export-expansion effect from the balance-sheet effect of an exchange rate depreciation. Finally, the merged database allows us to study firm exit, a margin of adjustment during the Korean crisis that has not heretofore been studied.

\subsection{Characteristics of Surviving Firms}

Table 1 provides summary statistics for surviving firms. We focus on the 1994-1999 sample period to capture the effects of the financial crisis. We exclude firms in the financial sector. In order to limit the influence of outliers, we eliminate observations in the top and bottom 1 percent of the sample in terms of the sales growth rate and the profit rate. When firms are sorted by industry, about 62 percent of firms are in the manufacturing sector, 14 percent in wholesale, retail trade and transportation, 11 percent in construction and utility, and another 13 percent provide other services. These industry shares are fairly constant over the 1994-1999 period. The full sample of firms, shown in line 1 of the top panel, starts with a sample size of 3,151 and increases over the 1994-1999 period. The increase in the sample size over time is not surprising given that the cutoff for coverage ( 7 billion won) is fixed in nominal terms; as the economy grows and there is inflation, the number of firms above this cutoff will obviously increase.

The mean age of firms (Table 1, line 2) is 15 to 17 years. In the first year, the median level of total assets (line 4) is 20 billion won, about triple the cutoff level for inclusion in the database. The mean level of real assets (line 3) is dramatically larger at 112 billion won, suggesting that the full sample covers many smaller firms. As we show below, inclusion of relatively small firms is critical for identifying the balancesheet effect on firm performance during the crisis.

The focus of our analysis will be firm performance during the crisis as measured by sales growth rates. ${ }^{10}$ Annual real sales growth rates and profit rates are shown

\footnotetext{
10 We also studied alternative performance measures of the pre-tax profit/sales ratio and the investment/capital ratio. The results are generally similar and are reported in the appendix.
} 
in lines 5 and 6 of the top panel of Table 1. The median real sales growth rate is in the 10-15 percent range in the pre-crisis period. The crisis occurred in late 1997, and median real sales growth drops off to 6.7 percent that year and then plummets to -10.3 percent in 1998 . The profit rate is defined as the ratio of the pre-tax profit and the previous-year sales. The median profit rate is around 3 percent in the pre-crisis years, and drops to 2 percent in 1997 and 2.3 percent in 1998.

Firm-level financial statistics are shown in lines 7 to 10 . The leverage ratio (line 7) is defined as total liabilities over total assets. The short-term debt ratio (line 8 ) is the share of short-term debt in total liabilities. The foreign debt ratio (line 9) is computed as the ratio of foreign debt to total liabilities. The short-term foreign debt ratio (line 10) is the share of short-term foreign debt in total liabilities. The mean leverage ratio declines after the crisis from $76 \%$ in $1994-1997$ to $67 \%$ in 1999 . The short-term debt ratio is relatively constant over the period of 1994-1999 at around $30 \%$. The foreign debt ratio is about $4 \%$ before the crisis and rises to $6 \%$ in 1997 in part due to the exchange rate depreciation. The short-term foreign debt ratio is about $1.7 \%$ before the crisis and rises to $2.2 \%$ in 1997 . The number of firms with foreign debt exposure (line 13) is large: about 40 percent of the full sample of firms carried foreign-currency denominated debt on their balance sheets in 1996. For those firms reporting foreign liabilities, the average foreign debt ratio was 12 percent in 1996.

Figure 2 compares the level of foreign currency debt of the banking sector and the sum of foreign currency debt of the firms in our sample. In both cases debt is decomposed into short-term and long-term debt, where short-term debt is defined as debt with original maturity of one year or less. External debt of both banks and private firms in our sample increased in the years preceding the crisis, with shortterm debt accounting for roughly half of all external liabilities. This pattern is not surprising because the majority of foreign debt holdings by Korean firms are channeled through the domestic banking sector. 
Previous analyses of emerging market crises suggest that exports may have provided firms with a natural hedge for foreign currency exposure-a depreciating currency will increase the cost of dollar-denominated debt service, but will increase the firm's competitiveness in foreign markets. ${ }^{11}$ Firm exports as a share of total sales are reported in line 11 of the top panel of Table 1 . The mean export/sales ratio is around 6 percent in our sample period. The fraction of exporting firms (line 12) in the full sample ranges from 13 to 20 percent. Conditional on exporting, the average export/sales ratio is around 30 percent.

The bottom panel of Table 1 reports summary statistics for publicly-listed firms, which account for 20 to 25 percent of the full sample. Publicly-listed firms are older, bigger and more profitable than an average firm in the full sample. They tend to have a smaller decline in sales growth during the financial crisis. They have somewhat lower leverage ratios and short-term debt ratios. They are also more exposed to foreign-currency denominated debt and are more likely to be exporters. Firms holding foreign-currency denominated debt constitute about 64 percent of the sample of publicly-listed firms but only 39 percent of the full sample in 1996. The fraction of firms that are exporters is about 27 percent among publicly-listed firms, while only 16 percent among the full sample in 1996. Conditional on having dollar debt, the mean foreign debt ratio and the export/sales ratio are similar across these two samples. $^{12}$

\footnotetext{
${ }^{11}$ See Aguiar (2005) for Mexico, Bleakley and Cowan (2008) for five Latin American countries, and Luengnaruemitchai (2003) for six East Asian countries.

12 Another group of Korean firms that has received a great deal of attention is the subset of firms belonging to chaebols. Chaebols are South Korean conglomerates composed of many companies clustered around one parent company. As the literature has emphasized, membership in a chaebol can provide insurance to firms through interlocking contracts and financial linkages. See Borensztein and Lee (2002), Lee et. al. (2000), and Min (2007). Our dataset includes roughly 230 firms that are part of the top 30 chaebols. Their characteristics tend to be similar to those of publicly-listed firms with several exceptions. First, the size of a chaebol firm, as measured by mean real assets, is more than twice the size of publicly-listed firms, and about seven times larger than the mean firm in the full sample. Second, the chaebols tend to have larger sales growth rates but lower profit rates than the publiclylisted firms. Third, the chaebols have much larger leverage ratios and greater exposure to foreign debt than the publicly-listed firms. Finally, the chaebols have smaller export/sales ratios than the publicly-
} 
An important issue is the extent to which our sample of firms is representative of the dynamics of the aggregate economy. While our empirical work will exploit heterogeneity between firms, our results could be viewed with suspicion if our sample of firms exhibits aggregate sales behavior during the crisis that is dramatically different from the dynamics of aggregate economic activity in Korea. To address this issue, Figure $3 \mathrm{a}$ shows the sum of firm sales as a ratio of GDP. The top line is the sum of all sample firms relative to GDP. The ratio is just under 1 in 1994 and increases to about 1.4 in 2000 as more firms are brought into the sample. ${ }^{13}$ The figure also shows the ratio for publicly-listed firms, which tops out at about 0.9. Figure $3 \mathrm{~b}$ compares the time series of real GDP growth over 1994-1999 to median real sales growth for our full sample of firms. Not surprisingly, there is more variation in the sales growth, but the shape of the two curves is similar. Both series pick up the dramatic fall in economic activity in 1998 and the recovery in 1999. This suggests that the patterns we see in firm-level data are consistent with aggregate macroeconomic dynamics.

\subsection{Characteristics of Liquidated Firms}

We now turn to liquidated firms in the sample. The KIS database provides a list of firms that submitted a notification of closing business to the court system and balance-sheet information for these firms before their liquidation. ${ }^{14}$ Table 2 provides summary statistics of firms that exited during the 1994-99 period-line numbers are identical to those in Table 1 for ease of comparison across the categories of firms.

listed firms. We include a chaebol dummy in our cross-section analysis to test for the role of network linkages on firm performance. No chaebols exited from the sample prior to the financial crisis.

13 These numbers are smaller than the output/GDP ratio for the US economy. Based on BEA data, the ratio of gross output of all industries excluding the financial industry to GDP ranges from 1.64 to 1.7 between 1994 and 2007. Thus, firm coverage of the KIS database might be somewhat less complete than the BEA coverage.

14 The list of liquidated firms does not include reorganized firms or firms that were sold to a foreign company. Thus, our exit data underestimate the severity of bankruptcy in crisis. The dataset does not allow us to precisely track entry. Firms may appear in the database either because they are newly established or because they reach the 7 billion won criterion. 
The exit rate ${ }^{15}$ in our sample — shown at the top of the table — was around 2 percent in the pre-crisis years, doubled to about 5 percent in 1997 and remained high at around 4 percent in 1998. The exit rate dropped to 1 percent in 1999. It should be noted that no publicly-listed firms filed a notification of closing throughout the 1994-1999 period. No chaebol firms exited before the crisis, and some did exit during the crisis.

Comparing liquidated firms with all firms (recall Table 1 and note that the statistics in Table 2 are for the year preceding firm exit), we see that liquidated firms tend to be younger and much smaller in size than the average firm. Before they exit, firm-level profit rates are very low and negative. ${ }^{16}$ Prior to exit, liquidated firms are less likely to be exporters and carry substantially more debt, particularly short-term debt, relative to the average firm. Liquidated firms are less likely to have foreign debt, and have smaller foreign debt ratios than the average firm. They also tend to be concentrated in the construction and manufacturing sectors.

In panel $\mathrm{B}$ of Table 2, we decompose the decline in annual aggregate firm sales growth into the drop in sales of surviving firms (the intensive margin), and the drop due to firm exit (the extensive margin). ${ }^{17}$ Consider the change in total firm sales between year $t$ and year $t+1$. Some firms in year $t$ continue in operation in year $t+1$, and we refer to these firms as "surviving firms." The remaining firms liquidate and exit, and we refer to them as "exiting firms." "The aggregate net sales growth equals the ratio of total sales of surviving firms in period $t+1$ and total sales of both surviving and liquidated firms in period $t$ minus 1 . We decompose aggregate sales growth into the intensive and extensive margin in the following way:

\footnotetext{
15 The exit rate in year $t$ is computed as the number of firms that exited in year $t$ divided by the sum of the number of surviving firms from year $t-1$ to $t$ and the number of firms that exited in year $t$.

${ }^{16}$ For exiting firms, we have only after-tax profits instead of pre-tax profits. The profit rate for exiting firms is thus computed using after-tax profits.

17 In this analysis, we abstract from the entry margin because the KIS dataset does not cover many entering firms. We doubt that the entry margin plays an important role during the financial crisis.

18 In this analysis, we ignore the contribution to total sales growth by firms that newly enter the database in period $t+1$.
} 


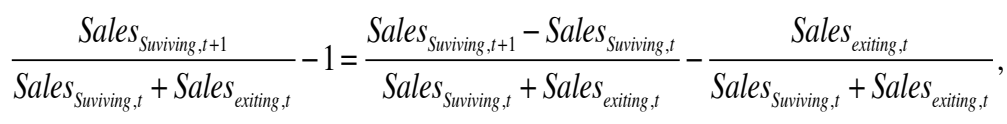

where the left hand side is the aggregate net sales growth, the first term on the right hand side is the intensive margin and the second term is the extensive margin. The intensive margin is the ratio of the change in total sales of surviving firms between year $t+1$ and $t$ and total sales in period $t$, and the extensive margin is the ratio of total sales of exiting firms and total sales of all firms in year $t$.

As the table shows, the contribution of the extensive margin to aggregate sales growth is small prior to the crisis-about 3 percent of total sales growth in our sample. In the crisis years, however, the extensive margin becomes substantially more important, accounting for 18 percent of the fall in aggregate sales growth in 1998.

\section{Cross-sectional Analysis of Firm Performance}

Before turning to the regression analysis, we first plot the time series of median sales growth for different subgroups of firms. We restrict the sample to the firms that report relevant statistics throughout 1994-1999. We classify firms into different groups according to their characteristics in 1996. Figure 4 shows median sales growth for firms by industry, firm size, export status, leverage, short-term debt and foreign debt as a share of total liabilities. The overwhelming message of Figure 4 is that the economic contraction was a macroeconomic phenomenon. While there are some differences across firms-for example sales of non-exporters contracted more sharply than exporters, and sales of the construction and utility industry had the deepest fall in 1998 - virtually all sectors and all types of firms experienced a deep contraction in 1998 and a sharp recovery in 1999. This suggests that to the extent differences in firm-level characteristics are important for understanding the crisis, they will only 
explain a fraction of the overall variation, and will likely work through interaction effects or through firm exit.

The general form for the cross-section regressions is shown in the following equation: ${ }^{19}$

$$
\text { SALES GROWTH }_{i}=\alpha+\beta \text { CHAR }_{i,-2}+\varepsilon_{i} .
$$

The dependent variable is firm is annual real sales growth. We perform the regression analysis for two time periods - the crisis period (characteristics in 1996 as explanators for the sales growth rate between 1997 and 1998) and the pre-crisis period (characteristics in 1994 as explanators for the sales growth rate between 1995 and 1996). ${ }^{20}$

In the baseline specification, firm-level characteristics include size (the log of firm real assets), age, chaebol status, leverage ratio, short-term debt ratio, export/sales ratio, and foreign debt ratio. All variables are in real Korean won. We include a two-digit industry dummy to control for industry-specific effects. In the second specification, we also include interaction effects between firm size with the foreign debt ratio, the leverage ratio, and the short-term debt ratio to allow these variables' effects on sales growth to differ by firm size. In the third specification, we de-

\footnotetext{
${ }_{19}$ Our goal is to account for the cross-sectional variation in firm performances during the crisis, and to relate this variation to firm-specific pre-crisis characteristics. An alternative would be to use a panel specification with firm fixed effects, and estimate how within-firm variation in debt holdings and export sales affects variation in firm performances over time. In that case, the impact of the crisis would be estimated through an interaction of lagged firm characteristics with the crisis dummy. We do not pursue this strategy for three reasons. First, such a specification would answer a different, much more narrow question: how does the crisis affect the relationship between debt holdings or export sales and sales growth within a firm? Second, firm fixed effects soak up explanatory power of interesting and informative time-invariant firm characteristics. Third, the short-time dimension of our dataset implies that we have limited variation to exploit.

20 We repeat the analysis with alternative measures of firm performance: the profit rate and the investment rate. The results are reported in the appendix. The main findings are broadly similar to those we report for sales growth. To ease exposition, we will focus primarily on the results for sales growth.
} 
compose the foreign debt ratio by maturity to examine whether firms with varying foreign debt maturities have differential firm performance.

\subsection{Cross-Section Results for Publicly-Listed Firms}

Table 3 shows the results for the sample of publicly-listed firms - the firms that have been carefully studied in previous analyses. Specifically, columns 1, 2 and 3 report the results for the crisis period, and columns 4, 5 and 6 report the results for the precrisis period. Our results confirm the results generally reported in the literature. In the pre-crisis period, chaebol status is positively related to firm performance while firm age is negatively related to firm performance. However, there is no significant effect of leverage, exports or balance-sheet variables. The results for the crisis period are somewhat different. Though the chaebol status continues to be positively related to firm growth, the age effect disappears. More importantly, the export/sales ratio now appears with a positive, statistically significant coefficient, confirming the export-expansion effect found in previous studies.

In terms of the balance-sheet effect, the first specification, in which financial variables are not interacted with firm size, presents a puzzling result. The coefficients on the leverage ratio and on the foreign debt ratio are significantly positive. This seems to suggest that firms entering the crisis with higher leverage ratios or higher foreign debt ratios had better performance during the crisis. The literature reports similar findings for publicly-listed firms (see Bleakley and Cowan 2009). When financial variables are interacted with size (columns 2 and 3) the positive coefficient disappears (the first clue that something different is going on for smaller firms) and the coefficients on financial variables are no longer statistically significant. Thus, an analysis based on publicly-listed firms would either suggest a positive role for foreign debt (if the size effect were omitted) or no role for financial variables in explaining firm performance. 
The positive coefficient on the foreign debt ratio in column 1 might be suggestive of potential omitted variable bias. If some firm characteristics that are positively correlated with a firm's ability to raise foreign debt and with its sales growth are omitted from our regression, the estimated coefficient on the foreign debt ratio would be biased upward. For example, publicly-listed firms with more foreign debt may better hedge against exchange rate risk through holding financial derivatives or foreign currency denominated assets. Their hedging decisions in turn might lead to smaller declines in sales growth during an exchange rate depreciation. Another example is that publicly-listed firms with more foreign debt may also have greater access to other forms of credit in the crisis, so they experience smaller declines in sales growth. Our dataset does not include the information on holdings of financial derivatives and foreign currency denominated assets and on accessibility to financing to control for these potential sources of bias. ${ }^{21}$

\subsection{Cross-Section Results for the Full Sample}

Table 4 repeats the analysis for a balanced sample of firms that includes small, privately-held firms. In the pre-crisis cross-section regression, we take the sample of firms in 1994 and hold that sample fixed through 1996. For the crisis cross-section regression, we take the sample of firms in 1996, holding the sample fixed through 1998. Note that this sample is about four times the size of the sample in Table 3. This analysis will still miss the impact of firm exit, however, as we include only those firms that survive for the three-year interval (1994-1996 in the pre-crisis regression and 1996-1998 in the crisis regression).

Turning first to the pre-crisis regression results in the right panel of Table 4, we see that the effects of chaebol status and age remain significant. Specifically, chaebols and younger firms are associated with faster sales growth. Moreover, there is no evidence of an export-expansion effect, similar to the results for publicly-listed

\footnotetext{
${ }^{21}$ Korean firms are required to disclose information about financial derivatives by law only after 2000 .
} 
firms in the pre-crisis period. The first specification (column 4) yields no significant effect for leverage, short-term debt or foreign debt ratios prior to the crisis. When these financial ratios are interacted with firm size (columns 5 and 6), leverage has a significant effect that varies with firm size. Higher leverage ratios are associated with faster sales growth rates for small firms, but slower sales growth rates for large firms. On the other hand, greater exposure to short-term debt is associated with slower sales growth rates, though the effect of short-term debt is smaller and may be positive for larger firms. Foreign debt ratios remain insignificant in the full sample of firms in the pre-crisis years.

The results are dramatically different during the crisis (the left panel of Table 4). There is a robust relationship between exports and firm sales: the coefficient on export status is positive and strongly significant across all three specifications. The effect is also economically significant. A ten percent increase in the pre-crisis export/sales ratio is associated with an increase in sales growth of approximately 2 percent during the crisis. This export-expansion effect is similar to what we find in the sample of publicly-listed firms.

The main difference across the two samples of firms is the balance-sheet effect. In contrast to the findings for publicly-listed firms, the full sample shows strong evidence of a negative balance-sheet effect on small firms. Again, if the financial variables are not interacted with size, the specification in column 1 of Table 4 yields a significantly positive coefficient on foreign debt. When we include interaction terms between financial variables and firm size in column 2 , the coefficient on foreign debt ratios turns significantly negative and the coefficient on the interaction term between foreign debt and size is significantly positive. Holding all the other variables constant, a one-percent larger foreign debt ratio affects sales growth by $(-2.817+0.134 \times$ size $)$ percent, which monotonically increases with firm size. The impact is negative for small firms, but positive for large firms. The critical size, below which the effect of foreign debt is negative is 21.02 in terms of $\log$ real assets and corresponds to a firm 
at about the bottom 2 percentile in the size distribution. Thus, for most firms, a higher foreign debt ratio is associated with a higher sales growth rate during the crisis. The negative balance-sheet effect shows up only for very small firms.

The negative balance-sheet effect on small firms is more prominent through short-term foreign debt. The coefficient on short-term foreign debt in column 3 is significant and large: -4.6. There is again an interaction effect with size-for large firms in the sample, the impact of short-term foreign debt is positive while for small firms the effect is negative. In this case, the cut-off point is 23.7 in terms of log real assets and corresponds to a firm at the $58^{\text {th }}$ percentile in the size distribution. Thus, for firms with assets below the $58^{\text {th }}$ percentile, an increase in the short-term foreign debt ratio is associated with a lower sales growth rate, all else equal. The effects are economically significant. Consider a firm with assets at the 10th percentile (log real asset of 22.1). A one percent increase in the short-term foreign debt ratio prior to the crisis is associated with a 0.31 percent lower rate of sales growth during the crisis. Note that the corresponding coefficients are similar for the sample of publicly-listed firms but were not statistically significant. ${ }^{22}$

There are at least two possible explanations for why significant balance-sheet effects emerge in the full sample but not in the smaller sample of publicly-listed firms. One reason may be that the larger number of observations and the greater variation in the full sample yield more explanatory power. The other reason may be that omitted variable bias is more severe in the sample of publicly-listed firms than the full sample. Our conjecture is that publicly-listed firms are more likely to hedge exchange rate risk and have access to other means of financing during the crisis, than other firms in the full sample. Our data do not provide enough information for us to determine the precise reasons for the difference between the two samples, but the

22 We included a dummy for foreign ownership to test the hypothesis that firms controlled by foreign owners have access to other credit channels and may have been buffered from the effects of the Korean crisis (see, for example, Kalemli-Ozcan et. al. 2009). Foreign-owned firms did not display different results from the full set of firms. 
results are suggestive that relying on publicly-listed firms will affect one's interpretation of the impact of the crisis at the micro level.

Omitted variable bias might also help understand our paradoxical finding for large firms in the full sample. Large firms tend to be publicly-listed firms, or to have similar characteristics as publicly-listed firms. We conjecture that the positive balance-sheet effect for large firms is due to omitted variable bias, although the exact interpretation of this finding is unclear. On the other hand, the possibility of potential upward bias from omitted variables might strengthen our conclusion about the negative balance-sheet effect on small firms.

The cross-section results based on the full sample support the view that both the export-expansion channel and the negative balance-sheet channel played a role during the crisis, with a particular role for exposure to short-term foreign debt. An interesting question is whether firms that were exposed to balance-sheet risk were also exporters, and therefore were at least partially hedged from the negative impact of the exchange rate devaluation. Table 5 shows the decomposition of firms by export status and foreign debt holdings. The table shows that the share of nonexporters among firms that held foreign debt is 71 percent in the full sample and 66 percent in the publicly-listed sample. (The breakdown is similar for short-term foreign debt.) Thus, a significant fraction of firms that entered the crisis with foreign debt did not have a natural hedge for their currency exposure. The ratio of "nonhedged" to "hedged" firms_as measured by export status—is higher in the full sample than in the publicly-listed firms: $2.4(=71 / 29)$ versus $1.9(=66 / 34)$. We find that the ratio decreases with firm size; the ratio is above $8(=89 / 11)$ for the smallest quartile and about $2(=68 / 32)$ for the largest quartile, indicating that small firms with foreign debt holdings were more exposed to exchange rate risk. 


\section{Firm Exit During the Financial Crisis}

The cross-section results pertain to firms that survived the crisis. We now perform an analysis of the factors that predict a firm's liquidation before and during the crisis. We find that foreign debt holdings are a significant predictor of firm exit, in particular for small firms, during the crisis. We then combine the intensive and extensive margin to examine the differential impact of foreign debt on firm performance by firm size.

\subsection{Predicting Firm Exit}

We run the following nonlinear probability regression on the panel of both surviving and exiting firms for the pre-crisis and crisis period:

$$
\mathrm{P}\left(\mathrm{EXIT}_{i}=1\right)=\Phi\left(\alpha+\theta \mathrm{CHAR}_{i,-1}\right)
$$

where P denotes the probability, EXIT is an indicator function of firm liquidation, and $\Phi$ denotes the logistic function. In the crisis period, the dependent variable is 1 if the firm exited in 1997 or 1998, and 0 otherwise. The independent variables are firm-specific observations in 1996, to capture the pre-crisis characteristics of the firm. In the pre-crisis period, the dependent variable is 1 if the firm exited in 1995 or 1996, and 0 otherwise. Firm characteristics on the right hand side are measured in 1994. Firm characteristics include chaebol status, age, one-digit industry dummy, size, export/sales ratios, profit/assets ratios, leverage ratios, short-term debt ratios,

and (short-term and long-term) foreign debt ratios. Comparing results before and during the crisis shows whether the factors that are correlated with the likelihood of firm exit during the crisis are different from those before the crisis.

The coefficients of the logit regressions are reported in Table 6. Turning first to the pre-crisis period (columns 4, 5 and 6) we see that relative to surviving firms, exiting firms tend to be younger and carry more debt, particularly short-term debt in 
the year preceding liquidation. Lower profits as a share of total assets significantly increase the probability of exit. Export status does not affect significantly the likelihood of exit. Turning next to the crisis period (columns 1, 2 and 3) we see weak evidence that being a chaebol member decreases the likelihood of exit. ${ }^{23}$ Younger firms continue to have larger exit probabilities. The role of profits is less important, while leverage and short-term debt become much more important. For a nonchaebol manufacturing firm with all characteristics at the mean level, the marginal effect of a higher leverage ratio on the exit probability is six times larger during the crisis than before the crisis. The marginal effect of a higher short-term debt ratio is four times larger. The coefficient on the export/sales ratio changes from positive in the precrisis period to negative in the crisis period, though it is still not statistically significant.

We next focus on the impact of foreign debt on firm exit. Columns 1 and 4 present a puzzling result that foreign debt does not significantly affect, if any it reduces, exit probabilities both pre-crisis and during the crisis. When interacted with firm size (columns 2, 3, 5 and 6), foreign debt has a significant effect, which varies with firm size, on the exit probabilities, suggesting that small firms with foreign debt are more likely to exit while large firms are less likely to exit. Though the coefficients on the foreign debt ratios and the interaction terms are similar pre-crisis and during the crisis, the marginal effects can be different. In a nonlinear model, the marginal effect of independent variables depends on all the covariates in the model. Especially for an interaction effect, not only the magnitude but also statistical significance varies by observation.

To examine the marginal effect of foreign debt across the two periods, the upper panel of Figure 5 plots the marginal effect of foreign debt on the exit probability (y-axis) before and during the crisis for nonchaebol manufacturing firms with

${ }^{23}$ Note that in the pre-crisis period, no chaebol firms were liquidated, and therefore we cannot compare across samples. Even during the crisis, chaebol firms tended to be restructured and absorbed by other firms rather than undergo complete liquidation. 
different size. We fix foreign debt ratios at the mean level conditional on having positive foreign debt and all the other variables at the mean level of the corresponding sample. The solid lines are the estimated marginal effect and the two dashed lines are the $95 \%$ confidence intervals. The marginal effect of foreign debt is significantly positive for small firms and significantly negative for large firms during the crisis. In contrast, the marginal effect of foreign debt pre-crisis is generally not significant except for very large firms. Thus, a larger foreign debt ratio raises exit probabilities of small firms only during the crisis.

During the crisis, for firms below the $54^{\text {th }}$ percentile of the size distribution, a larger foreign debt ratio predicts a higher likelihood of exit, and for firms above, a larger foreign debt ratio lowers the probability of exit. For example, for a firm with size at the $10^{\text {th }}$ percentile and all other variables at the mean level, an increase in the pre-crisis foreign debt ratio of one percentage point is expected to increase the probability of exit during the crisis by 0.28 percentage points. In contrast, if the firm is in the top decile, a one-percentage point increase in the foreign debt ratio is expected to decrease the probability of exit by 0.23 percentage points. Similar findings hold for both the short-term and long-term foreign debt ratios.

The likelihood of exit also differs by firm size and across the two sample periods. The lower panel of Figure 5 plots the estimated likelihood of exit for the same set of firms as in the upper panel. Clearly, the predicted exit rates are higher across all firm size during the crisis than before the crisis. A firm with size at the $10^{\text {th }}$ percentile has a probability of exit at 7.3 percent, while a firm with size at the $90^{\text {th }}$ percentile has a probability of exit at 4.7 percent during the crisis. In contrast, the predicted exit rate before the crisis is only 3.5 percent for a firm with size at the $10^{\text {th }}$ percentile and 1.4 percent for a firm at the $90^{\text {th }}$ percentile. 


\subsection{Counterfactual exercise}

The previous results suggest that there are important interaction effects between firm size and foreign debt, and that these effects vary across both the extensive and intensive margins. In addition, we find that the export sales are a natural hedge to foreign currency debt during the crisis. In this subsection we perform counterfactual exercises to illustrate the roles played by these various factors in accounting for the drop in firm sales during the financial crisis.

We first consider a counterfactual scenario in which each firm in our sample increases its pre-crisis leverage ratio by 10 percentage points and all of the additional borrowing is in the form of short-term foreign debt. We hold all of the other precrisis firm characteristics unchanged. The regression results of Column 3 of Table 4 are used to calculate the counterfactual sales growth of each firm in this scenario, conditional on survival. We then compute the average sales growth rate, weighted by 1997 sales, for each asset quartile and for the economy as a whole. Column 1 of Table 7 reports the predicted sales growth given firm characteristics as observed in 1996, and column 2 reports the predicted sales growth given the counterfactual foreign debt levels. The results illustrate the range of the impact of foreign debt on sales by firm size. Larger short-term foreign debt lowers the sales growth of small firms, but increases the sales growth of large firms. Specifically, the first (smallest) quartile sees a decline in the sales growth rate from $-2.9 \%$ to $-4.5 \%$, while the fourth (largest) quartile sees an increase from $-13.5 \%$ to $-9 \%$. The aggregate sales growth rate rises from $-12.6 \%$ to $-8.6 \%$ because large firms are dominant in overall sales growth.

We next turn to the extensive margin using the logit results in column 3 of Table 6. Recall that larger short-term foreign debt ratios increase the exit probability of small firms, but reduce the exit probability of large firms. The average probabilities of exit for each asset quartile given the observed characteristics and given the 
counterfactual short-term foreign debt ratios are reported in column 4 and 5 of Table 7 , respectively. Increasing short-term foreign debt leads to a doubling of the exit probability of firms in the smallest quartile from $7.2 \%$ to $14.6 \%$, while it reduces the exit probability of firms in the largest quartile from $6.2 \%$ to $4.5 \%$. The overall exit rate rises from $7 \%$ to $9.3 \%$ as the foreign debt holdings increase in the economy.

We now combine the extensive and intensive margins by computing the average of the predicted sales growth rate conditional on survival and the sales growth rate of -1 conditional on exit, weighted by the survival and exit probability, respectively. See column 7 and 8 of Table 7 . Incorporating both effects, we find that increasing short-term foreign debt is associated with a decline in the sales growth rate by 7.6 percentage points for firms in the smallest quartile, but is associated with a rise of the sales growth rate by 5.7 percentage points for firms in the largest quartile. This result suggests that the impact of foreign debt depends critically on what types of firms take on foreign debt. If foreign debt is concentrated in the balance sheets of large firms, which have ways to hedge against the currency depreciation in the crisis, foreign debt is not necessarily detrimental to firms' performance. On the other hand, if foreign debt is concentrated in the balance sheets of small firms, the decline in predicted sales growth is large. Note also that the extensive margin explains the majority of the decline of sales growth for most firms in the sample. For example, the extensive margin accounts for 80 percent of the decline in sales for the smallest quartile and 73 percent for the second smallest quartile. These numbers underscore the importance of taking firm exit into account when evaluating the effects of the crisis.

We conduct the second counterfactual experiment on the potentially mitigating role played by export sales during the crisis. In this scenario, we set all exporters' export/sales ratio to zero, to essentially eliminate any of the natural hedging effect of firm exports on sales growth. The predicted sales growth rates conditional on survival are reported in column 3 of Table 7. From the cross-section regression results, we know that higher export/sales ratios are associated with better firm performance. 
Thus, it is not surprising that the counterfactual export/sales ratios lead to lower sales growth rates for all asset quartiles and especially in the largest asset quartile where most of the exporting firms appear. Overall sales growth also declines from $-12.6 \%$ to $-14.6 \%$. Since the export/sales ratio does not have a large role in explaining exit probabilities, the extensive margin (reported in column 6 of Table 7) changes little from column 4. This suggests that to the extent exports provided a natural hedge for the exchange rate depreciation, they did so primarily for the largest firms in the sample and they did not shield small firms from the risk of bankruptcy during the crisis.

\section{Conclusion}

Using Korean firm-level data on both publicly-listed and privately-held firms and firm exit data, this paper finds evidence of a balance-sheet effect and an exportexpansion effect. Before the crisis, firm sales growth was uncorrelated with foreign debt holdings and export sales. During the crisis, however, small firms holding more foreign debt, in particular, short-term foreign debt, experienced larger declines in sales growth. Firms with higher export/sales ratios have smaller declines in sales growth during the crisis. In addition, we find that small firms with short-term foreign debt are significantly more likely to go bankrupt during the crisis. The extensive margin accounts for a large fraction of small firms' adjustment during the crisis.

There are two caveats to these conclusions. The first is that the results in this paper pertain primarily to differential firm performance in the cross-section. As shown in Figure 4, most of the variation in the data is at the macro level. That is, our results can only explain whether firms with more foreign debt holdings have sharper declines in sales than firms with smaller holdings and we do not claim to provide an explanation for the overall decline in firm sales. Second, the regression analyses take firm characteristics (size, debt ratios, export status, etc.) as given in ex- 
plaining next period's sales growth. Obviously, many firm characteristics are themselves choice variables, and a complete model would endogenize the full menu of firm characteristics, including firm debt, exposure to foreign currency risk and export status. We leave a more complete analysis that would address these caveats for future research. 


\section{References}

Aguiar, Mark, 2005. "Investment, devaluation, and foreign currency exposure: The case of Mexico," Journal of Development Economics 78, 95-113.

Bayraktar, Nihal, Plutarchos Sakellaris and Philip Vermeulen, 2005. "Real Versus Financial Frictions to Capital Investment," European Central Bank Working Paper 566.

Benavente, Jose Miguel, Christian A. Johnson, and Felipe G. Morande, 2003. "Debt composition and balance sheet effects of exchange rate depreciations: a firm-level analysis for Chile," Emerging Markets Review 4 (2003) 368-396.

Bleakley, Hoyt and Kevin Cowan, 2008. "Corporate dollar debt and depreciations: Much ado about nothing?” The Review of Economics and Statistics 90(4), 612-626.

Bleakley, Hoyt and Kevin Cowan, 2009. "Mishmash on Mismatch? Balance-Sheet Effects and Emerging-Markets Crises,” Working Paper, University of Chicago.

Bonomo, Marco, Betina Martins, and Rodrigo Pinto. 2003. "Debt composition and exchange rate balance sheet effect in Brazil: a firm level analysis," Emerging Markets Review 4 (2003) 368-396.

Borensztein, Eduardo and Jong-Wha Lee, 2002. "Financial crisis and credit crunch in Korea: evidence from firm-level data," Journal of Monetary Economics 49, 853-875.

Carranza, Luis J., Juan M. Cayo, Jose E. Galdon-Sanchez, 2003. "Exchange rate volatility and economic performance in Peru: firm level analysis," Emerging Markets Review 4 (2003) 472-496.

Céspedes, Luis J., Chang, Roberto and Andrés Velasco, 2004. "Balance sheets and exchange rate policy," The American Economic Review 94(4), 1183-93.

Corsetti, Giancarlo, Paolo Presenti and Nouriel Roubini, 1998. "What caused the Asian currency and financial crisis? Part I: Macroeconomic Overview," NBER working paper 6833.

Echeverrya, Juan Carlos, Leopoldo Fergussona, Roberto Steinerb, and Camila Aguilara, 2003. "Dollar debt in Colombian firms: are sinners punished during devaluations?” Emerging Markets Review 4 (2003) 417-449.

Feldstein, Martin, 1999. "Self-protection for emerging market economies," NBER Working Paper 6907. 
Forbes, Kristine J. 2002. "How do large depreciations affect firm performance?" IMF staff papers 49.

Gilchrist, Simon and Jae W. Sim, 2007. "Investment during the Korean financial crisis: a structural econometric analysis,” NBER working paper 13315.

Kalemli-Ozcan, Sebnem, Herman Kamil, and Carolina Villegas-Sanchez, 2009. "What Hinders investment in the aftermath of financial crises: balance-sheet mismatches or access to finance?” Working paper, University of Huston.

Krugman, Paul, 1999. "Balance sheets, the transfer problem, and financial crises," International Tax and Public Finance 6(4), 459-472.

Kwon, Taek Ho, 2005. "Asymmetric Exchange Rate Exposure and Foreign Currency Denominated Debt," Working paper, Chonnam National University.

Lee, Jong-Wha, Young Soo Lee and Byung-Sun Lee, 2000. "The determination of corporate debt in Korea, Asian Economic Journal 14, 333-356.

Luengnaruemitchai, Pipat, 2003. "The Asian crisis and the mystery of the missing balance sheet effect," Working paper, University of California, Berkeley.

Martínez, Lorenza and Alejandro Werner, 2002. "The exchange rate regime and the currency composition of corporate debt: the Mexican experience," Journal of Development Economics, 69 (2002) 315-334.

Min, Byung, 2007. "Changing pattern of corporate governance and financing in the Korean Chaebols," Economic Papers 26(3), 211-230.

Pratapa, Sangeeta, Ignacio Lobatoa, and Alejandro Somuanob, 2003. "Debt composition and balance sheet effects of exchange rate volatility in Mexico: a firm level analysis," Emerging Markets Review 4 (2003) 450-471. 


\section{Appendix}

In this appendix, we report the cross-section regression results for two alternative measures of firm performance: the profit rate and the investment rate. We first describe the results on the profit rate. In the crisis regressions, the dependent variable, i.e., the profit rate, is pre-tax profits in 1998 as a share of sales in 1997. In the precrisis regressions, the profit rate is pre-tax profits in 1996 as a share of sales in 1995. The independent variables are the same as in the sales growth regressions. We run the regressions for both the publicly-listed firms (Table A1) and the full sample (Table A2). The results on the balance sheet effect and the export-expansion effect are very similar to the results with sales growth. Firms entering the crisis with larger foreign debt ratios have higher profit rates during the crisis (see column 1 of both tables). However, when interacting with firm size, the coefficients on the foreign debt ratio becomes negative and the coefficients on the interaction term become positive. Thus, the negative balance sheet effect shows up for small firms. This effect is not statistically significant for publicly listed firms, but it is significant at the ten percent level for the full sample and the short-term foreign debt ratio.

We then look at the results with firm performance measured by the investment rate. The investment rate is the ratio of real investment to the lagged replacement value of real capital stock. In the crisis regression, the dependent variable is firm real investment in 1998 as a share of the replacement value of real capital stock in 1997. In the pre-crisis regression, the dependent variable is firm real investment in 1996 as a share of the replacement value of real capital in 1995. The independent variables include all the characteristics that we examined for the sales growth rate and the profit rate. In addition, we also include the lagged dependent variable as an additional regressor to pick up the persistence effect of investment.

Before introducing the results, we explain the construction of the investment rate in more details. For real investment $\left(I_{t}\right)$, nominal investment is first constructed by $I_{t}^{n}=K_{t}^{b}-K_{t-1}^{b}+D e p_{t}$, where $K_{t}^{b}$ is calculated by subtracting land and lease assets 
from tangible assets (all in book values from the balance sheets), and $D_{e} p_{t}$ is taken from the cash flow statements. Real investment is nominal investment deflated by capital goods price index. The replacement value of real capital stock $\left(K_{t}\right)$ is calculated by iterating $K_{t}=(1-d) K_{t-1}+I_{t}$ backward, where $I_{t}$ is real investment constructed as above and the economic depreciation rate $d$ is assumed to be $11 \%$, which is an average depreciation of building, structure, vehicle and machine in South Korea. The initial capital stock is measured as the real book value of capital in the year that a firm first appears the data set. ${ }^{24}$

We report the results for the publicly-listed firms in Table A3, and the results for the full sample in Table A4. For the publicly-listed firms, the balance-sheet effect and the export-expansion effect do not show up significantly in all specifications during the crisis and before the crisis. For the full sample, we find evidence for both effects. Larger export/sales ratios are statistically significantly associated with higher investment rates only during the crisis. Small firms with larger foreign debt ratios have lower investment rates both during the crisis and before the crisis. The maturity structure of foreign debt holdings does not matter for the investment rate during the crisis. Before the crisis, small firms with larger long-term foreign debt ratios have lower investment rates.

\footnotetext{
${ }^{24}$ We follow Bayraktar et. al. (2005) in constructing the investment rate.
} 


\section{Figure 1: Aggregate Data}

(a) Major Real Macro Variables (annual, 1997 level normalized to 1)

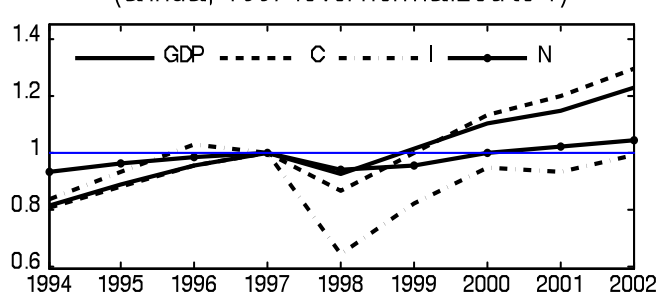

(c) External Debt / GDP (\%, annual)

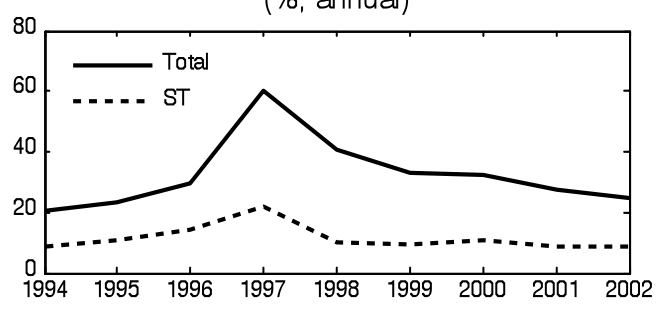

(e) Nominal Exchange Rate (KRW/USD, monthly)

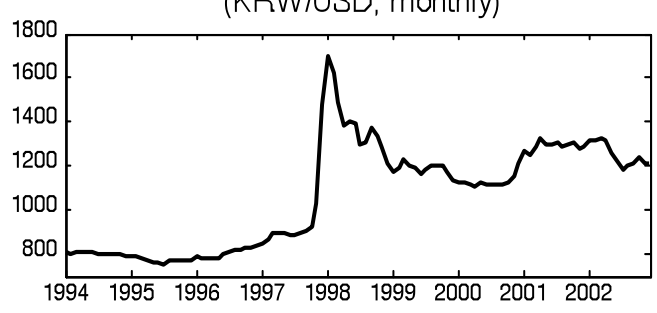

(b) Current Account/ GDP

(\%, annual)

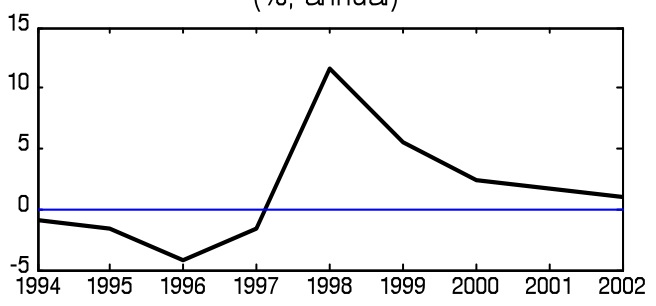

(d) Total Private Credit / GDP

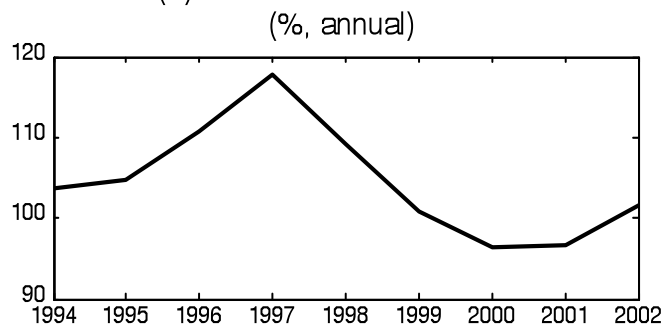

(f) Money Market Rate (\%, monthly)

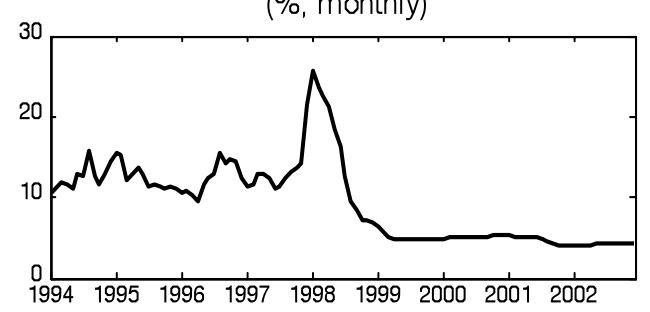

Note: The data source is Korea National Statistical Office. 
Figure 2: Aggregate and Firm-Level Debt Data

External Debt

(billion dollar, end of year)

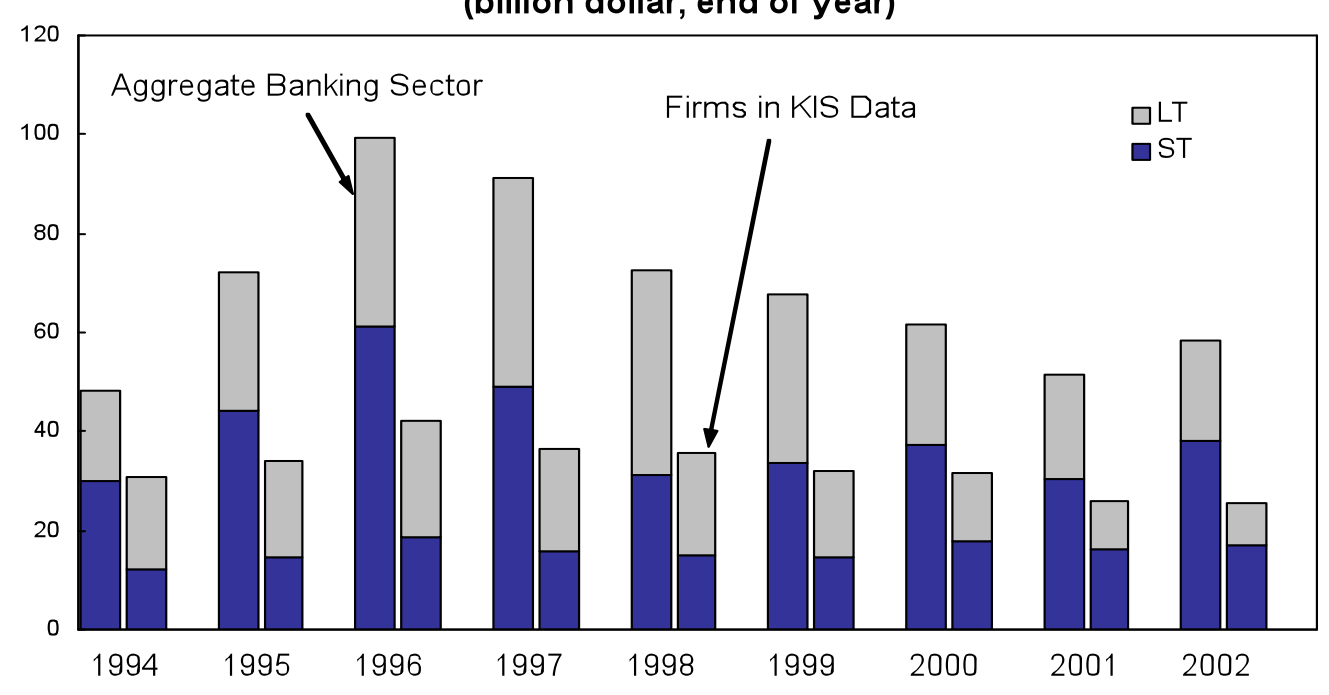

Note: Short-term debt has original maturity equal to or less than one year. The aggregate debt statistics come from Korea National Statistical Office, and the firm-level debt statistics come from the KIS-VALUE dataset. 


\section{Figure 3: Comparison of Firm Sales and GDP}

(a) Sum of Firm Sales / GDP

$$
\text { (annual) }
$$

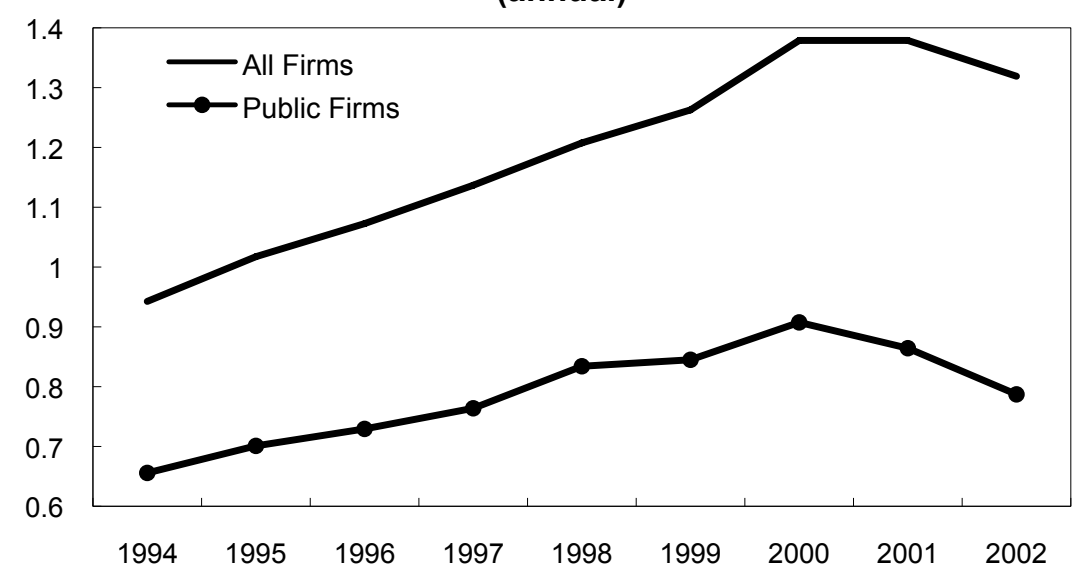

(b) Real GDP and Firm Sales Growth (annual, \%)

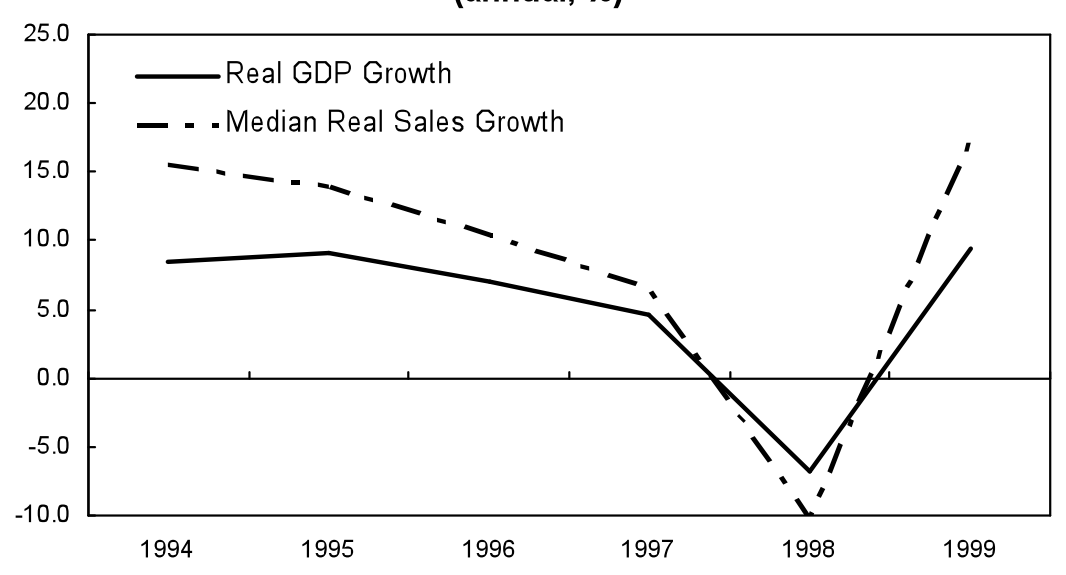

Note: The data sources are Korea National Statistical Office and the KIS-VALUE dataset. 


\section{Figure 4: Sales Growth of Firms with Varying Characteristics}

(a) Median Sales Growth by Industry

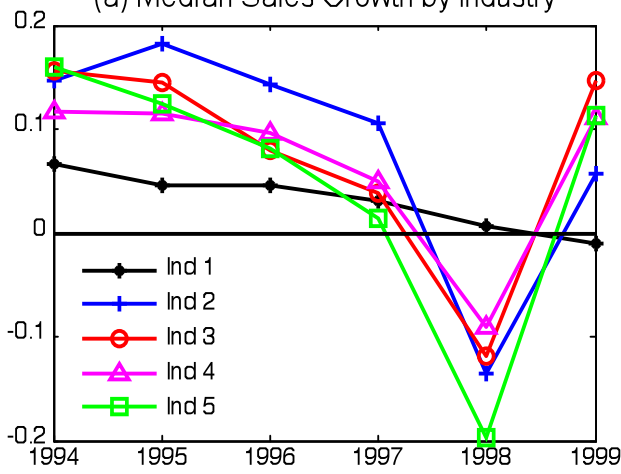

(d) Median Sales Growth by Leverage

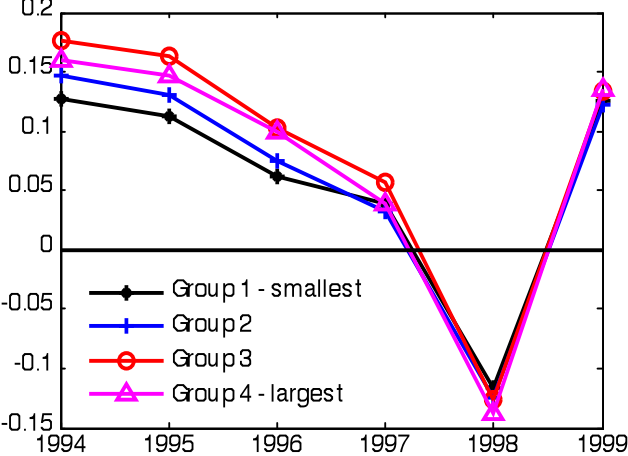

(b) Median Sales Growth by Firm Size

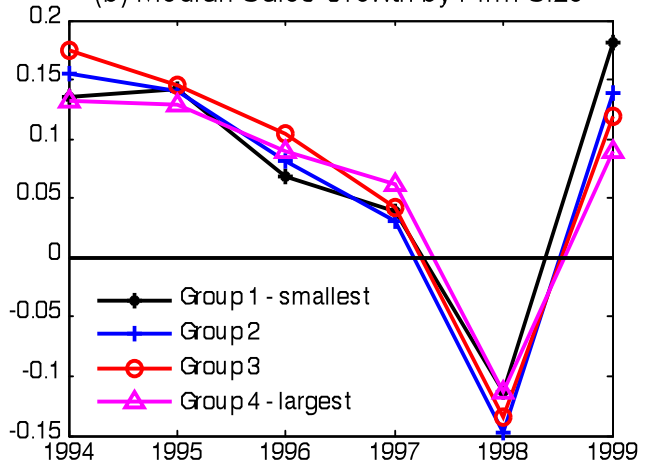

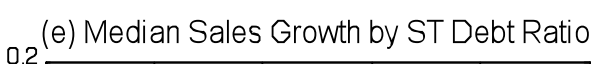

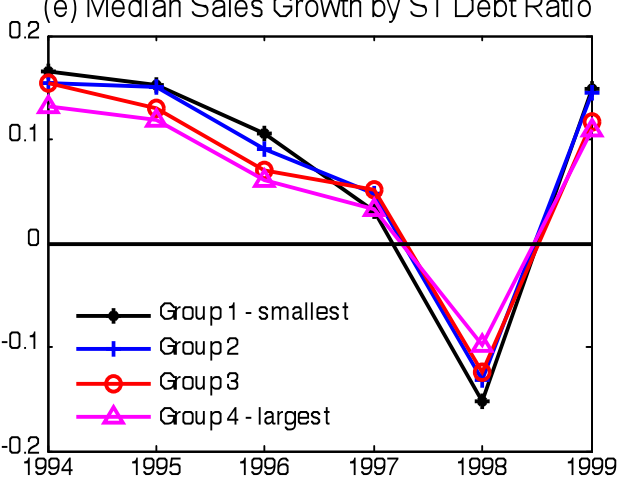

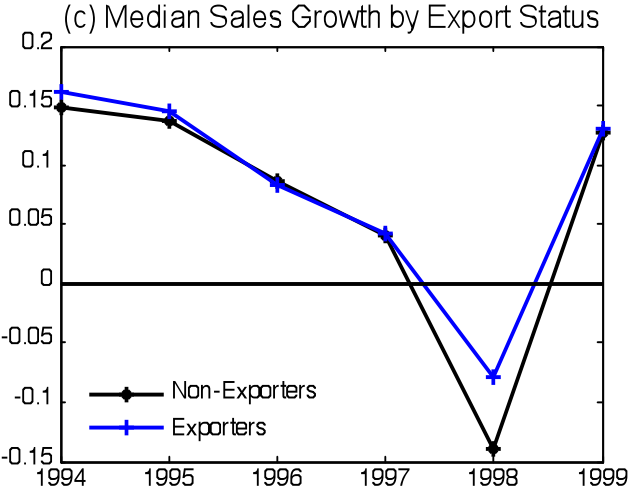

(f) Median Sales Growth by Foreign Debt Ratio

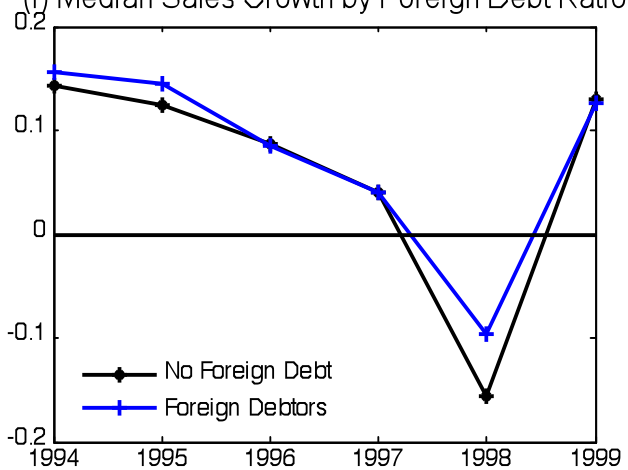

Note: Industry 1 is Agriculture, Forestry, Fishing, and Mining; Industry 2 is Construction and Utility; Industry 3 is Manufacturing; Industry 4 is Wholesale and Retail Trade and Transportation; Industry 5 is Other Services. The data source is the KIS-VALUE dataset. 
Figure 5: LOGIT Regression Results
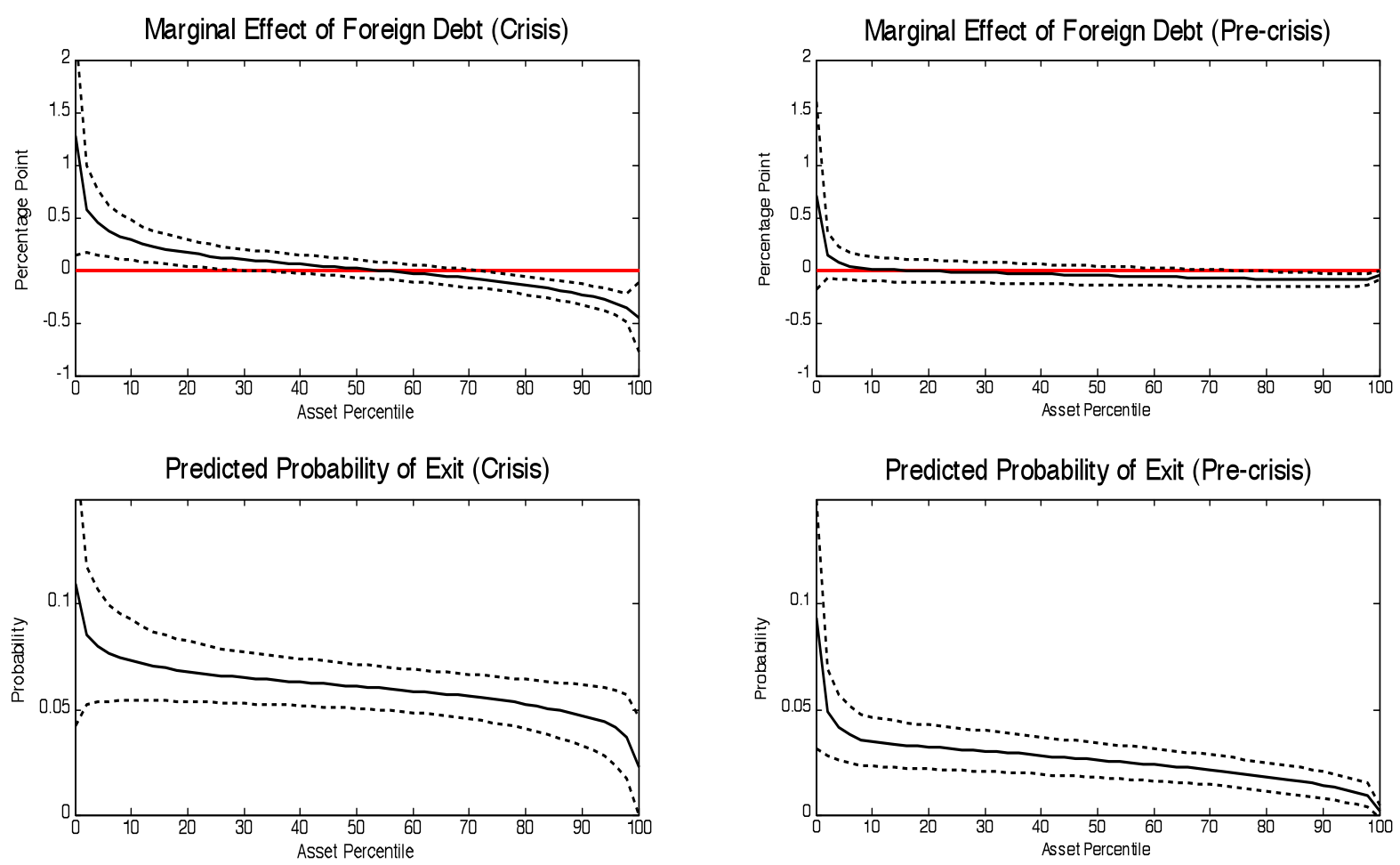

Note: In the upper panel, the solid lines plot the marginal effect of foreign debt on the exit probability for nonchaebol manufacturing firms with different size, the foreign debt ratio at the mean level conditional on having positive foreign debt, and all the other variables at the mean level of the sample. In the lower panel, the solid lines plot the estimated probability of exit for the same set of firms as in the upper panel. The left panel is for the crisis period, and the right panel is for the pre-crisis period. The dashed lines are the $95 \%$ confidence intervals. 


\section{Table 1: Summary Statistics for Surviving Firms}

\begin{tabular}{|c|c|c|c|c|c|c|c|}
\hline & & 1994 & 1995 & 1996 & 1997 & 1998 & 1999 \\
\hline & & \multicolumn{6}{|c|}{ All Firms } \\
\hline 1 & Number of Firms & 3,151 & 3,956 & 4,285 & 5,066 & 5,476 & 5,606 \\
\hline 2 & Mean Age & 17 & 17 & 16 & 16 & 15 & 15 \\
\hline 3 & Mean Real Assets & 112 & 114 & 109 & 120 & 95 & 101 \\
\hline 4 & Median Real Assets & 20 & 19 & 16 & 15 & 11 & 11 \\
\hline 5 & Median Real Sales Growth Rate (\%) & 15.3 & 13.9 & 10.5 & 6.7 & -10.3 & 19.6 \\
\hline 6 & Median Profit Rate $(\%)$ & 3.3 & 2.9 & 2.6 & 2.0 & 2.3 & 4.7 \\
\hline 7 & Mean Leverage Ratio (\%) & 76.0 & 76.6 & 76.5 & 77.1 & 72.0 & 67.3 \\
\hline 8 & Mean ST Debt Ratio (\%) & 30.5 & 30.7 & 30.4 & 29.7 & 30.4 & 29.7 \\
\hline 9 & Mean Foreign Debt Ratio (\%) & 4.3 & 4.4 & 4.4 & 6.0 & 5.3 & 4.3 \\
\hline 10 & Mean ST Foreign Debt Ratio (\%) & 1.6 & 1.8 & 1.8 & 2.2 & 1.9 & 1.9 \\
\hline 11 & Mean Export/Sales Ratio (\%) & 7.7 & 7.1 & 6.0 & 5.2 & 5.6 & 4.7 \\
\hline 12 & Fraction of Exporters (\%) & 20.1 & 17.3 & 16.3 & 14.0 & 13.6 & 13.2 \\
\hline \multirow[t]{2}{*}{13} & Fraction of Firms with Foreign Debt (\%) & 43.9 & 39.4 & 38.7 & 38.0 & 34.5 & 31.8 \\
\hline & & \multicolumn{6}{|c|}{ Publicly-Listed Firms } \\
\hline 1 & Number of Firms & 881 & 959 & 988 & 1,046 & 1,049 & 1,064 \\
\hline 2 & Mean Age & 22 & 22 & 21 & 22 & 22 & 22 \\
\hline 3 & Mean Real Assets & 274 & 294 & 327 & 385 & 338 & 395 \\
\hline 4 & Median Real Assets & 49 & 47 & 45 & 47 & 37 & 40 \\
\hline 5 & Median Real Sales Growth Rate (\%) & 14.8 & 14.5 & 9.7 & 7.0 & -7.8 & 16.7 \\
\hline 6 & Median Profit Rate (\%) & 3.9 & 3.6 & 3.0 & 2.4 & 2.8 & 7.1 \\
\hline 7 & Mean Leverage Ratio (\%) & 71.0 & 70.8 & 70.4 & 71.7 & 67.1 & 59.0 \\
\hline 8 & Mean ST Debt Ratio (\%) & 28.2 & 28.6 & 28.4 & 28.9 & 28.4 & 25.7 \\
\hline 9 & Mean Foreign Debt Ratio (\%) & 6.1 & 6.3 & 6.8 & 8.8 & 7.3 & 6.4 \\
\hline 10 & Mean ST Foreign Debt Ratio (\%) & 2.7 & 3.0 & 3.2 & 4.0 & 3.2 & 3.5 \\
\hline 11 & Mean Export/Sales Ratio (\%) & 11.3 & 10.6 & 9.7 & 8.3 & 9.1 & 8.3 \\
\hline 12 & Fraction of Exporters (\%) & 30.5 & 28.5 & 26.7 & 22.9 & 22.3 & 19.5 \\
\hline 13 & Fraction of Firms with Foreign Debt (\%) & 66.5 & 64.7 & 64.0 & 62.2 & 60.5 & 53.9 \\
\hline
\end{tabular}

Note: Real assets are in billion 1994 won. The profit rate is defined as the ratio of the pre-tax profit and the previous-year sales. The leverage ratio is defined as total liabilities over total assets. The ST debt ratio is defined as the amount of debt with original maturity less than or equal to one year divided by total liabilities. The foreign debt ratio is defined as foreign debt as a share of total liabilities. The ST foreign debt ratio is defined as short-term foreign debt over total liabilities. We remove the top and bottom $1 \%$ observations in terms of the sales growth rate and the profit rate. 


\section{Tables 2: Summary Statistics for Liquidated Firms}

\section{Panel A:}

$1 \quad$ Number of Exited Firms

Exit Rate (\%)

$\begin{array}{rrrrr}1995 & 1996 & 1997 & 1998 & 1999 \\ 71 & 100 & 218 & 206 & 57 \\ 2.2 & 2.5 & 4.8 & 3.9 & 1.0\end{array}$

\begin{tabular}{rrrrr}
\multicolumn{5}{c}{ Characteristics of Year Before Exit } \\
1994 & 1995 & 1996 & 1997 & 1998 \\
11 & 9 & 10 & 12 & 12 \\
17 & 18 & 20 & 25 & 15 \\
13 & 13 & 13 & 12 & 11 \\
& & & & \\
11.3 & 17.1 & 5.4 & 3.2 & -41.6 \\
0.4 & -0.7 & 0.1 & -4.4 & -12.6 \\
& & & & \\
92.7 & 98.3 & 96.3 & 104.0 & 112.7 \\
41.0 & 38.2 & 38.5 & 41.0 & 36.2 \\
2.5 & 1.3 & 3.3 & 3.3 & 3.9 \\
1.0 & 0.6 & 1.1 & 1.2 & 0.8 \\
6.6 & 3.4 & 3.5 & 3.0 & 2.0 \\
12.7 & 5.0 & 10.6 & 5.8 & 5.3 \\
22.5 & 16.0 & 25.7 & 28.2 & 24.6
\end{tabular}

Percentage of Exited Firms in

$$
\begin{aligned}
& \text { Industry } 1 \\
& \text { Industry } 2 \\
& \text { Industry } 3 \\
& \text { Industry } 4 \\
& \text { Industry } 5
\end{aligned}
$$

\section{Panel B:}

Aggregate Sales Growth Intensive Margin

Extensive Margin

$\%$ of aggregate sales growth

\begin{tabular}{rrrrr}
4 & 2 & 1 & 2 & 0 \\
34 & 41 & 35 & 32 & 32 \\
51 & 44 & 54 & 44 & 54 \\
7 & 8 & 8 & 15 & 5 \\
4 & 5 & 2 & 7 & 9 \\
\multicolumn{5}{c}{ tensive versus Intensive Margin } \\
18.06 & 12.49 & 10.19 & -7.21 & 11.53 \\
18.39 & 12.89 & 11.22 & -5.91 & 11.69 \\
-0.34 & -0.40 & -1.03 & -1.30 & -0.16 \\
-1.87 & -3.21 & -10.21 & 18.01 & -1.41 \\
\hline
\end{tabular}

Note: Exited firms are firms that are liquidated. The exit rate of year $t$ is computed as the ratio of the number of exited firms in year $t$ and the sum of the number of firms survived from year $t-1$ to $t$ and the number of firms exited in year $t$. Characteristic statistics of exited firms are reported for the year preceding the liquidation. The profit rate for exited firms is computed as the ratio of the after-tax profit and the previous-year sales since we don't have pre-tax profits for exited firms. The aggregate sales growth is computed as the total sales of all surviving firms in period $t+1$ divided by the total sales of both surviving and exited firms in period $t$. We measure the intensive margin with the ratio of the total sales of surviving firms in year $t+1$ and $t$, and measure the extensive margin as the ratio of the total year-t sales of exited firms and the total sales of all firms in year $t$. Industry 1 is Agriculture, Forestry, Fishing, and Mining; Industry 2 is Construction and Utility; Industry 3 is Manufacturing; Industry 4 is Wholesale and Retail Trade and Transportation; Industry 5 is Other Services. 
Table 3: Cross-Section Regressions for Publicly-Listed Firms

\begin{tabular}{|c|c|c|c|c|c|c|}
\hline \multirow{2}{*}{$\begin{array}{l}\text { Dependent Variable: } \\
\text { Sales Growth }\end{array}$} & \multicolumn{3}{|c|}{ Crisis } & \multicolumn{3}{|c|}{ Pre-Crisis } \\
\hline & 1 & 2 & 3 & 4 & 5 & 6 \\
\hline Chaebol Dummy & $\begin{array}{l}0.098 * * \\
(0.038)\end{array}$ & $\begin{array}{l}0.101 * * \\
(0.041)\end{array}$ & $\begin{array}{l}0.098^{* *} \\
(0.041)\end{array}$ & $\begin{array}{l}0.086^{* *} \\
(0.037)\end{array}$ & $\begin{array}{l}0.091 * * \\
(0.037)\end{array}$ & $\begin{array}{l}0.088^{* *} \\
(0.038)\end{array}$ \\
\hline Age & $\begin{array}{l}0.000 \\
(0.001)\end{array}$ & $\begin{array}{l}0.000 \\
(0.002)\end{array}$ & $\begin{array}{l}0.000 \\
(0.002)\end{array}$ & $\begin{array}{l}-0.002^{* * *} \\
(0.001)\end{array}$ & $\begin{array}{l}-0.002^{* * *} \\
(0.001)\end{array}$ & $\begin{array}{l}-0.002^{* * *} \\
(0.001)\end{array}$ \\
\hline Size & $\begin{array}{l}-0.077 * * * \\
(0.017)\end{array}$ & $\begin{array}{l}0.031 \\
(0.090)\end{array}$ & $\begin{array}{l}0.033 \\
(0.090)\end{array}$ & $\begin{array}{l}-0.026^{* *} \\
(0.011)\end{array}$ & $\begin{array}{l}-0.017 \\
(0.037)\end{array}$ & $\begin{array}{l}-0.019 \\
(0.036)\end{array}$ \\
\hline Leverage Ratio & $\begin{array}{l}0.248^{* *} \\
(0.117)\end{array}$ & $\begin{array}{l}4.150 \\
(3.286)\end{array}$ & $\begin{array}{l}4.265 \\
(3.272)\end{array}$ & $\begin{array}{l}-0.031 \\
(0.047)\end{array}$ & $\begin{array}{l}0.837 \\
(0.831)\end{array}$ & $\begin{array}{l}0.713 \\
(0.810)\end{array}$ \\
\hline Size * Leverage Ratio & & $\begin{array}{l}-0.162 \\
(0.132)\end{array}$ & $\begin{array}{l}-0.167 \\
(0.132)\end{array}$ & & $\begin{array}{l}-0.035 \\
(0.034)\end{array}$ & $\begin{array}{l}-0.030 \\
(0.033)\end{array}$ \\
\hline ST Debt Ratio & $\begin{array}{l}-0.204 \\
(0.129)\end{array}$ & $\begin{array}{l}-1.426 \\
(1.809)\end{array}$ & $\begin{array}{l}-1.434 \\
(1.907)\end{array}$ & $\begin{array}{l}-0.032 \\
(0.076)\end{array}$ & $\begin{array}{l}-1.705 \\
(1.365)\end{array}$ & $\begin{array}{l}-1.484 \\
(1.503)\end{array}$ \\
\hline Size * ST Debt Ratio & & $\begin{array}{l}0.053 \\
(0.072)\end{array}$ & $\begin{array}{l}0.058 \\
(0.077)\end{array}$ & & $\begin{array}{l}0.069 \\
(0.055)\end{array}$ & $\begin{array}{l}0.061 \\
(0.061)\end{array}$ \\
\hline Export/Sales Ratio & $\begin{array}{l}0.211 * * * \\
(0.060)\end{array}$ & $\begin{array}{l}0.185^{* * *} \\
(0.060)\end{array}$ & $\begin{array}{l}0.163^{* *} \\
(0.064)\end{array}$ & $\begin{array}{l}-0.038 \\
(0.047)\end{array}$ & $\begin{array}{l}-0.032 \\
(0.049)\end{array}$ & $\begin{array}{l}-0.035 \\
(0.049)\end{array}$ \\
\hline Foreign Debt Ratio & $\begin{array}{l}0.623^{* *} \\
(0.302)\end{array}$ & $\begin{array}{l}-0.503 \\
(4.539)\end{array}$ & & $\begin{array}{l}0.017 \\
(0.163)\end{array}$ & $\begin{array}{l}0.348 \\
(2.430)\end{array}$ & \\
\hline Size * Foreign Debt Ratio & & $\begin{array}{l}0.044 \\
(0.174)\end{array}$ & & & $\begin{array}{l}-0.014 \\
(0.095)\end{array}$ & \\
\hline ST Foreign Debt Ratio & & & $\begin{array}{l}-4.464 \\
(3.325)\end{array}$ & & & $\begin{array}{l}-2.920 \\
(1.849)\end{array}$ \\
\hline Size * ST Foreign Debt Ratio & & & $\begin{array}{l}0.180 \\
(0.131)\end{array}$ & & & $\begin{array}{l}0.109 \\
(0.074)\end{array}$ \\
\hline LT Foreign Debt Ratio & & & $\begin{array}{l}1.982 \\
(9.503)\end{array}$ & & & $\begin{array}{l}1.316 \\
(2.917)\end{array}$ \\
\hline Size $*$ LT Foreign Debt Ratio & & & $\begin{array}{l}-0.029 \\
(0.361)\end{array}$ & & & $\begin{array}{l}-0.047 \\
(0.116)\end{array}$ \\
\hline Observations & 988 & 988 & 988 & 881 & 881 & 881 \\
\hline R-squared & 0.158 & 0.176 & 0.189 & 0.156 & 0.160 & 0.164 \\
\hline
\end{tabular}

Note: The dependent variable is firm sales growth between 1997 and 1998 for the crisis regressions and sales growth rate between 1995 and 1996 for the pre-crisis regressions. The independent variables are for year 1996 in the crisis regressions and for year 1994 in the pre-crisis regressions. Robust standard errors are reported in parentheses. ${ }^{* * *}$ denotes a pvalue less than $1 \%$, $* *$ denotes a $\mathrm{p}$-value less than $5 \%$, and $*$ denotes a p-value less than $10 \%$. All regressions include industry dummies at the two-digit level. 


\section{Table 4: Cross-Section Regressions for the Full Sample}

\begin{tabular}{|c|c|c|c|c|c|c|}
\hline \multirow{2}{*}{$\begin{array}{l}\text { Dependent Variable: } \\
\text { Sales Growth }\end{array}$} & \multicolumn{3}{|c|}{ Crisis } & \multicolumn{3}{|c|}{ Pre-Crisis } \\
\hline & 1 & 2 & 3 & 4 & 5 & 6 \\
\hline Chaebol Dummy & $\begin{array}{l}0.095^{* * *} \\
(0.027)\end{array}$ & $\begin{array}{l}0.087^{* * *} \\
(0.027)\end{array}$ & $\begin{array}{l}0.087 * * * \\
(0.027)\end{array}$ & $\begin{array}{l}0.076^{* * *} \\
(0.022)\end{array}$ & $\begin{array}{l}0.076^{* * *} \\
(0.022)\end{array}$ & $\begin{array}{l}0.072 * * * \\
(0.024)\end{array}$ \\
\hline Age & $\begin{array}{l}0.000 \\
(0.001)\end{array}$ & $\begin{array}{l}0.000 \\
(0.001)\end{array}$ & $\begin{array}{l}0.000 \\
(0.001)\end{array}$ & $\begin{array}{l}-0.002 * * * \\
(0.001)\end{array}$ & $\begin{array}{l}-0.002^{* * *} \\
(0.001)\end{array}$ & $\begin{array}{l}-0.002 * * * \\
(0.001)\end{array}$ \\
\hline Size & $\begin{array}{l}-0.055^{* * *} \\
(0.007)\end{array}$ & $\begin{array}{l}0.002 \\
(0.025)\end{array}$ & $\begin{array}{l}-0.001 \\
(0.025)\end{array}$ & $\begin{array}{l}-0.021 \text { *** } \\
(0.006)\end{array}$ & $\begin{array}{l}0.003 \\
(0.023)\end{array}$ & $\begin{array}{l}0.003 \\
(0.022)\end{array}$ \\
\hline Leverage Ratio & $\begin{array}{l}0.105^{* * *} \\
(0.038)\end{array}$ & $\begin{array}{l}1.490^{*} \\
(0.883)\end{array}$ & $\begin{array}{l}1.517 * \\
(0.882)\end{array}$ & $\begin{array}{l}0.050 \\
(0.035)\end{array}$ & $\begin{array}{l}1.425^{* *} \\
(0.607)\end{array}$ & $\begin{array}{l}1.363^{* *} \\
(0.613)\end{array}$ \\
\hline Size $*$ Leverage Ratio & & $\begin{array}{l}-0.059 \\
(0.037)\end{array}$ & $\begin{array}{l}-0.060 \\
(0.037)\end{array}$ & & $\begin{array}{l}-0.058^{* *} \\
(0.025)\end{array}$ & $\begin{array}{l}-0.055^{* *} \\
(0.026)\end{array}$ \\
\hline ST Debt Ratio & $\begin{array}{l}-0.026 \\
(0.044)\end{array}$ & $\begin{array}{l}1.380^{*} \\
(0.801)\end{array}$ & $\begin{array}{l}1.172 \\
(0.820)\end{array}$ & $\begin{array}{l}0.017 \\
(0.059)\end{array}$ & $\begin{array}{l}-1.445^{*} \\
(0.842)\end{array}$ & $\begin{array}{l}-1.214 \\
(0.867)\end{array}$ \\
\hline Size * ST Debt Ratio & & $\begin{array}{l}-0.060^{*} \\
(0.034)\end{array}$ & $\begin{array}{l}-0.050 \\
(0.035)\end{array}$ & & $\begin{array}{l}0.062^{*} \\
(0.035)\end{array}$ & $\begin{array}{l}0.052 \\
(0.036)\end{array}$ \\
\hline Export/Sales Ratio & $\begin{array}{l}0.192^{* * *} \\
(0.032)\end{array}$ & $\begin{array}{l}0.182^{* * *} \\
(0.032)\end{array}$ & $\begin{array}{l}0.182^{* * * *} \\
(0.031)\end{array}$ & $\begin{array}{l}-0.030 \\
(0.028)\end{array}$ & $\begin{array}{l}-0.028 \\
(0.028)\end{array}$ & $\begin{array}{l}-0.028 \\
(0.028)\end{array}$ \\
\hline Foreign Debt Ratio & $\begin{array}{l}0.417 * * * \\
(0.109)\end{array}$ & $\begin{array}{l}-2.817 * * \\
(1.326)\end{array}$ & & $\begin{array}{l}0.138 \\
(0.096)\end{array}$ & $\begin{array}{l}-1.297 \\
(1.782)\end{array}$ & \\
\hline Size $*$ Foreign Debt Ratio & & $\begin{array}{l}0.134 * * \\
(0.053)\end{array}$ & & & $\begin{array}{l}0.059 \\
(0.074)\end{array}$ & \\
\hline ST Foreign Debt Ratio & & & $\begin{array}{l}-4.600^{* * *} \\
(1.655)\end{array}$ & & & $\begin{array}{l}-5.501 \\
(3.597)\end{array}$ \\
\hline Size * ST Foreign Debt Ratio & & & $\begin{array}{l}0.194 * * * \\
(0.067)\end{array}$ & & & $\begin{array}{l}0.228 \\
(0.154)\end{array}$ \\
\hline LT Foreign Debt Ratio & & & $\begin{array}{l}-2.705 \\
(2.173)\end{array}$ & & & $\begin{array}{l}0.990 \\
(2.238)\end{array}$ \\
\hline Size * LT Foreign Debt Ratio & & & $\begin{array}{l}0.141 \\
(0.087)\end{array}$ & & & $\begin{array}{l}-0.034 \\
(0.092)\end{array}$ \\
\hline Observations & 4,285 & 4,285 & 4,285 & 3,151 & 3,151 & 3,151 \\
\hline R-squared & 0.093 & 0.099 & 0.102 & 0.059 & 0.063 & 0.064 \\
\hline
\end{tabular}

Note: The dependent variable is firm sales growth between 1997 and 1998 for the crisis regressions and sales growth rate between 1995 and 1996 for the pre-crisis regressions. The independent variables are for year 1996 in the crisis regressions and for year 1994 in the pre-crisis regressions. Robust standard errors are reported in parentheses. ${ }^{* * *}$ denotes a pvalue less than $1 \%$, $* *$ denotes a $\mathrm{p}$-value less than $5 \%$, and $*$ denotes a p-value less than $10 \%$. All regressions include industry dummies at the two-digit level. 
Table 5: Joint Distribution of Foreign Debt and Export Status

\begin{tabular}{|c|c|c|c|c|c|c|}
\hline & \multicolumn{3}{|c|}{ Firms with Foreign Debt } & \multicolumn{3}{|c|}{ Firms with No Foreign Debt } \\
\hline & $\begin{array}{c}\text { Total } \\
\text { Number }\end{array}$ & $\begin{array}{c}\text { Fraction of } \\
\text { Exporters (\%) }\end{array}$ & $\begin{array}{c}\text { Fraction of } \\
\text { Non-Exporters }(\%)\end{array}$ & $\begin{array}{c}\text { Total } \\
\text { Number }\end{array}$ & $\begin{array}{c}\text { Fraction of } \\
\text { Exporters }(\%)\end{array}$ & $\begin{array}{c}\text { Fraction of } \\
\text { Non-Exporters }(\%)\end{array}$ \\
\hline $\begin{array}{l}\text { Full Sample } \\
\text { Asset bins }\end{array}$ & 1,660 & 28.73 & 71.27 & 2,625 & 8.50 & 91.50 \\
\hline 1 & 83 & 10.84 & 89.16 & 988 & 5.06 & 94.94 \\
\hline 2 & 384 & 24.22 & 75.78 & 687 & 11.64 & 88.36 \\
\hline 3 & 497 & 30.38 & 69.62 & 574 & 9.93 & 90.07 \\
\hline 4 & 696 & 32.18 & 67.82 & 376 & 9.57 & 90.43 \\
\hline $\begin{array}{l}\text { Publicly- } \\
\text { listed Firms }\end{array}$ & 632 & 34.18 & 65.82 & 356 & 13.48 & 86.52 \\
\hline
\end{tabular}

Note: A firm is classified as an exporter if its export/sales ratio is positive, and as a non-exporter otherwise. A firm is classified as a foreign debt holder if its foreign debt holdings are positive, and as a non-foreign-debt holder otherwise. Firms are classified into four equal number bins according to their size. The smallest firms are in asset bin 1, and the largest firms are in bin 4 . 


\section{Table 6: Coefficients in Logit Exit Regressions}

\begin{tabular}{|c|c|c|c|c|c|c|}
\hline & \multicolumn{3}{|c|}{ Crisis } & \multicolumn{3}{|c|}{ Pre-Crisis } \\
\hline & 1 & 2 & 3 & 4 & 5 & 6 \\
\hline Chaebol Dummy & $\begin{array}{c}-0.654 * \\
(0.364)\end{array}$ & $\begin{array}{l}-0.540 \\
(0.365)\end{array}$ & $\begin{array}{l}-0.531 \\
(0.365)\end{array}$ & & & \\
\hline Age & $\begin{array}{c}-0.033^{* * *} \\
(0.008)\end{array}$ & $\begin{array}{c}-0.033^{* * *} \\
(0.008)\end{array}$ & $\begin{array}{c}-0.032 * * * \\
(0.008)\end{array}$ & $\begin{array}{c}-0.049 * * * \\
(0.011)\end{array}$ & $\begin{array}{c}-0.049 * * * \\
(0.011)\end{array}$ & $\begin{array}{c}-0.049 * * * \\
(0.011)\end{array}$ \\
\hline Size & $\begin{array}{l}0.086^{*} \\
(0.046)\end{array}$ & $\begin{array}{c}0.153 * * * \\
(0.048)\end{array}$ & $\begin{array}{c}0.149 * * * \\
(0.048)\end{array}$ & $\begin{array}{c}-0.173 * * * \\
(0.065)\end{array}$ & $\begin{array}{c}-0.114 * \\
(0.067)\end{array}$ & $\begin{array}{l}-0.103 \\
(0.067)\end{array}$ \\
\hline Leverage Ratio & $\begin{array}{c}2.278^{* * *} \\
(0.397)\end{array}$ & $\begin{array}{c}2.176^{* * *} \\
(0.389)\end{array}$ & $\begin{array}{c}2.168^{* * *} \\
(0.387)\end{array}$ & $\begin{array}{c}0.815^{* * *} \\
(0.302)\end{array}$ & $\begin{array}{c}0.787 * * * \\
(0.300)\end{array}$ & $\begin{array}{c}0.786^{* * *} \\
(0.302)\end{array}$ \\
\hline ST Debt Ratio & $\begin{array}{c}1.691 * * * \\
(0.289)\end{array}$ & $\begin{array}{c}1.678^{* * *} \\
(0.291)\end{array}$ & $\begin{array}{c}1.727 * * * \\
(0.296)\end{array}$ & $\begin{array}{c}0.921 * * \\
(0.420)\end{array}$ & $\begin{array}{c}0.909 * * \\
(0.420)\end{array}$ & $\begin{array}{c}0.875^{* *} \\
(0.425)\end{array}$ \\
\hline Profit/Assets & $\begin{array}{c}-2.066^{*} \\
(1.234)\end{array}$ & $\begin{array}{c}-2.160^{*} \\
(1.186)\end{array}$ & $\begin{array}{c}-2.145^{*} \\
(1.190)\end{array}$ & $\begin{array}{c}-3.637 * * * \\
(0.935)\end{array}$ & $\begin{array}{c}-3.658 * * * \\
(0.936)\end{array}$ & $\begin{array}{c}-3.681 * * * \\
(0.936)\end{array}$ \\
\hline Export/Sales Ratio & $\begin{array}{l}-0.576 \\
(0.460)\end{array}$ & $\begin{array}{l}-0.509 \\
(0.455)\end{array}$ & $\begin{array}{l}-0.509 \\
(0.457)\end{array}$ & $\begin{array}{c}0.364 \\
(0.549)\end{array}$ & $\begin{array}{c}0.456 \\
(0.541)\end{array}$ & $\begin{array}{c}0.455 \\
(0.543)\end{array}$ \\
\hline Foreign Debt Ratio & $\begin{array}{l}-0.038 \\
(0.725)\end{array}$ & $\begin{array}{c}61.090^{* * *} \\
(12.880)\end{array}$ & & $\begin{array}{l}-0.874 \\
(1.866)\end{array}$ & $\begin{array}{c}60.510^{* * *} \\
(22.410)\end{array}$ & \\
\hline Size $*$ Foreign Debt Ratio & & $\begin{array}{c}-2.608^{* * *} \\
(0.555)\end{array}$ & & & $\begin{array}{c}-2.669 * * * \\
(0.994)\end{array}$ & \\
\hline ST Foreign Debt Ratio & & & $\begin{array}{c}72.640 * * * \\
(27.160)\end{array}$ & & & $\begin{array}{l}92.060^{*} \\
(52.370)\end{array}$ \\
\hline Size * ST Foreign Debt Ratio & & & $\begin{array}{c}-3.146^{* * *} \\
(1.173)\end{array}$ & & & $\begin{array}{c}-3.944^{*} \\
(2.254)\end{array}$ \\
\hline LT Foreign Debt Ratio & & & $\begin{array}{c}48.980 * * * \\
(16.990)\end{array}$ & & & $\begin{array}{c}61.000^{* *} \\
(30.740)\end{array}$ \\
\hline Size * LT Foreign Debt Ratio & & & $\begin{array}{c}-2.058^{* * *} \\
(0.742)\end{array}$ & & & $\begin{array}{c}-2.731^{*} \\
(1.412)\end{array}$ \\
\hline Observations & 4,696 & 4,696 & 4,696 & 3,398 & 3,398 & 3,398 \\
\hline Pseudo R-squared & 0.156 & 0.162 & 0.162 & 0.135 & 0.139 & 0.139 \\
\hline
\end{tabular}

Note: The dependent variable is either 1 if the firm exits in 1997 or in 1998, or 0 otherwise for the crisis regressions, and is either 1 if the firm exits in 1995 or in 1996, or 0 otherwise in the pre-crisis regressions. The independent variables are for 1996 in the crisis regressions and for 1994 for the pre-crisis regressions. Robust standard errors are reported in parentheses. ${ }^{* *}$ denotes a p-value less than $1 \%, * *$ denotes a p-value less than $5 \%$, and $*$ denotes a p-value less than $10 \%$. All regressions include industry dummies at the one-digit level. 
Table 7: Differential Impact of Short-term Foreign Debt

\begin{tabular}{|c|c|c|c|c|c|c|c|c|c|}
\hline \multirow{3}{*}{$\begin{array}{l}\text { Asset } \\
\text { bins }\end{array}$} & \multicolumn{3}{|c|}{ Intensive margin: sales growth } & \multicolumn{3}{|c|}{ Extensive margin: exit probability } & \multicolumn{3}{|c|}{ Both margins: sales growth } \\
\hline & $\begin{array}{c}\text { Observed } \\
\text { characteristics }\end{array}$ & $\begin{array}{l}\text { Counterfactual } \\
\text { foreign debt }\end{array}$ & $\begin{array}{c}\text { Counterfactual } \\
\text { export sales }\end{array}$ & $\begin{array}{c}\text { Observed } \\
\text { characteristics }\end{array}$ & $\begin{array}{l}\text { Counterfactual } \\
\text { foreign debt }\end{array}$ & $\begin{array}{l}\text { Counterfactual } \\
\text { export sales }\end{array}$ & $\begin{array}{c}\text { Observed } \\
\text { characteristics }\end{array}$ & $\begin{array}{l}\text { Counterfactual } \\
\text { foreign debt }\end{array}$ & $\begin{array}{l}\text { Counterfactual } \\
\text { export sales }\end{array}$ \\
\hline & 1 & 2 & 3 & 4 & 5 & 6 & 7 & 8 & 9 \\
\hline 1 & $-2.9 \%$ & $-4.5 \%$ & $-3.2 \%$ & $7.2 \%$ & $14.6 \%$ & $7.3 \%$ & $-10.1 \%$ & $-17.7 \%$ & $-10.5 \%$ \\
\hline 2 & $-4.7 \%$ & $-5.4 \%$ & $-6.0 \%$ & $7.6 \%$ & $10.5 \%$ & $7.8 \%$ & $-12.8 \%$ & $-15.4 \%$ & $-14.1 \%$ \\
\hline 3 & $-8.5 \%$ & $-7.8 \%$ & $-9.9 \%$ & $6.9 \%$ & $7.7 \%$ & $7.1 \%$ & $-15.0 \%$ & $-15.0 \%$ & $-16.4 \%$ \\
\hline 4 & $-13.5 \%$ & $-9.0 \%$ & $-15.7 \%$ & $6.2 \%$ & $4.5 \%$ & $6.4 \%$ & $-16.2 \%$ & $-10.5 \%$ & $-18.5 \%$ \\
\hline Total & $-12.6 \%$ & $-8.6 \%$ & $-14.6 \%$ & $7.0 \%$ & $9.3 \%$ & $7.1 \%$ & $-15.9 \%$ & $-11.1 \%$ & $-17.9 \%$ \\
\hline
\end{tabular}

Note: Firms are classified into four equal number bins according to their size. The smallest firms are in asset bin 1, and the largest firms are in bin 4 . The statistics under the intensive margin are predicted sales growth using the regression estimates in column 3 of Table 4 . The statistics under the extensive margin are predicted exit probabilities computed using column 3 of Table 6 . The sales growth under both margins is computed as the average of the predicted sales growth rate conditional on survival and the sales growth rate of -1 conditional on exit weighted by the survival and exit probability, respectively. The columns under observed characteristics are computed using the 1996 observables for each firm. The columns under counterfactual foreign debt are computed for the scenario in which each firm has a 10-percentage-point hypothetical increase of its leverage ratio through increasing short-term foreign debt holdings and all the other variables as observed in the data. The columns under counterfactual export sales are computed for the scenario in which all firms have zero export/sales ratios and all the other variables as observed in the data. 


\section{Table A1: Profit Regressions for Publicly Listed Firms}

\begin{tabular}{|c|c|c|c|c|c|c|}
\hline \multirow{2}{*}{$\begin{array}{l}\text { Dependent Variable } \\
\text { Profit/Sales-1 }\end{array}$} & \multicolumn{3}{|c|}{ Crisis } & \multicolumn{3}{|c|}{ Pre-Crisis } \\
\hline & 1 & 2 & 3 & 4 & 5 & 6 \\
\hline Chaebol Dummy & $\begin{array}{l}0.024 \\
(0.024)\end{array}$ & $\begin{array}{l}0.024 \\
(0.025)\end{array}$ & $\begin{array}{l}0.023 \\
(0.025)\end{array}$ & $\begin{array}{l}0.001 \\
(0.011)\end{array}$ & $\begin{array}{c}0.004 \\
(0.011)\end{array}$ & $\begin{array}{l}0.003 \\
(0.011)\end{array}$ \\
\hline Age & $\begin{array}{l}0.001 \\
(0.001)\end{array}$ & $\begin{array}{c}0.001 \\
(0.001)\end{array}$ & $\begin{array}{l}0.001 \\
(0.001)\end{array}$ & $\begin{array}{c}-0.001 * * \\
(0.000)\end{array}$ & $\begin{array}{c}-0.001 * * \\
(0.000)\end{array}$ & $\begin{array}{c}-0.001^{* *} \\
(0.000)\end{array}$ \\
\hline Size & $\begin{array}{c}-0.036 * * * \\
(0.006)\end{array}$ & $\begin{array}{l}-0.008 \\
(0.019)\end{array}$ & $\begin{array}{l}-0.007 \\
(0.020)\end{array}$ & $\begin{array}{c}-0.009 * * \\
(0.004)\end{array}$ & $\begin{array}{l}0.018 \\
(0.017)\end{array}$ & $\begin{array}{l}0.019 \\
(0.017)\end{array}$ \\
\hline Leverage & $\begin{array}{c}-0.091 * * * \\
(0.034)\end{array}$ & $\begin{array}{c}0.687 \\
(0.570)\end{array}$ & $\begin{array}{c}0.708 \\
(0.570)\end{array}$ & $\begin{array}{c}-0.040^{*} \\
(0.024)\end{array}$ & $\begin{array}{l}0.895^{*} \\
(0.517)\end{array}$ & $\begin{array}{l}0.889 * \\
(0.523)\end{array}$ \\
\hline Size $*$ Leverage & & $\begin{array}{l}-0.032 \\
(0.024)\end{array}$ & $\begin{array}{l}-0.033 \\
(0.024)\end{array}$ & & $\begin{array}{c}-0.038^{*} \\
(0.021)\end{array}$ & $\begin{array}{c}-0.038^{*} \\
(0.021)\end{array}$ \\
\hline ST Debt Ratio & $\begin{array}{c}-0.063^{* *} \\
(0.031)\end{array}$ & $\begin{array}{l}0.496 \\
(0.436)\end{array}$ & $\begin{array}{l}0.494 \\
(0.473)\end{array}$ & $\begin{array}{c}-0.071 * * * \\
(0.023)\end{array}$ & $\begin{array}{l}0.018 \\
(0.302)\end{array}$ & $\begin{array}{l}0.096 \\
(0.335)\end{array}$ \\
\hline Size * ST Debt Ratio & & $\begin{array}{l}-0.023 \\
(0.018)\end{array}$ & $\begin{array}{l}-0.022 \\
(0.020)\end{array}$ & & $\begin{array}{l}-0.004 \\
(0.012)\end{array}$ & $\begin{array}{l}-0.007 \\
(0.014)\end{array}$ \\
\hline Export/Sales Ratio & $\begin{array}{c}0.133^{* * *} \\
(0.021)\end{array}$ & $\begin{array}{c}0.125 * * * \\
(0.021)\end{array}$ & $\begin{array}{c}0.121 * * * \\
(0.021)\end{array}$ & $\begin{array}{l}0.025^{*} \\
(0.014)\end{array}$ & $\begin{array}{l}0.025^{*} \\
(0.014)\end{array}$ & $\begin{array}{l}0.025^{*} \\
(0.014)\end{array}$ \\
\hline Foreign Debt Ratio & $\begin{array}{c}0.205^{* * *} \\
(0.055)\end{array}$ & $\begin{array}{l}-0.748 \\
(0.753)\end{array}$ & & $\begin{array}{l}-0.013 \\
(0.046)\end{array}$ & $\begin{array}{l}-0.388 \\
(0.480)\end{array}$ & \\
\hline Size * Foreign Debt Ratio & & $\begin{array}{c}0.038 \\
(0.030)\end{array}$ & & & $\begin{array}{c}0.015 \\
(0.019)\end{array}$ & \\
\hline ST Foreign Debt Ratio & & & $\begin{array}{l}-1.443 \\
(0.962)\end{array}$ & & & $\begin{array}{l}-0.369 \\
(0.716)\end{array}$ \\
\hline Size * ST Foreign Debt Ratio & & & $\begin{array}{l}0.062 \\
(0.039)\end{array}$ & & & $\begin{array}{l}0.017 \\
(0.029)\end{array}$ \\
\hline LT Foreign Debt Ratio & & & $\begin{array}{l}-0.314 \\
(1.438)\end{array}$ & & & $\begin{array}{l}-0.179 \\
(0.760)\end{array}$ \\
\hline Size * LT Foreign Debt Ratio & & & $\begin{array}{c}0.026 \\
(0.058)\end{array}$ & & & $\begin{array}{l}0.004 \\
(0.030)\end{array}$ \\
\hline Observations & 988 & 988 & 988 & 881 & 881 & 881 \\
\hline R-squared & 0.182 & 0.189 & 0.192 & 0.19 & 0.202 & 0.204 \\
\hline
\end{tabular}

Note: The dependent variable is firm profits in 1998 as a share of sales in 1997 for the crisis regressions and firm profits in 1996 as a share of sales in 1995 for the pre-crisis regressions. The independent variables are for year 1996 in the crisis regressions and for year 1994 in the pre-crisis regressions. Robust standard errors are reported in parentheses. ${ }^{* * *}$ denotes a $\mathrm{p}$-value less than $1 \%$, ${ }^{* *}$ denotes a p-value less than $5 \%$, and $*$ denotes a p-value less than $10 \%$. All regressions include industry dummies at the two-digit level. 


\section{Table A2: Profit Regressions for the Full Sample}

\begin{tabular}{|c|c|c|c|c|c|c|}
\hline \multirow{2}{*}{$\begin{array}{l}\text { Dependent Variable } \\
\text { Profit/Sales-1 }\end{array}$} & \multicolumn{3}{|c|}{ Crisis } & \multicolumn{3}{|c|}{ Pre-Crisis } \\
\hline & 1 & 2 & 3 & 1 & 2 & 3 \\
\hline Chaebol Dummy & $\begin{array}{l}-0.015 \\
(0.018)\end{array}$ & $\begin{array}{l}-0.013 \\
(0.018)\end{array}$ & $\begin{array}{l}-0.014 \\
(0.018)\end{array}$ & $\begin{array}{l}0.015^{*} \\
(0.009)\end{array}$ & $\begin{array}{l}0.017 * \\
(0.009)\end{array}$ & $\begin{array}{l}0.016^{*} \\
(0.009)\end{array}$ \\
\hline Age & $\begin{array}{c}0.000 \\
(0.000)\end{array}$ & $\begin{array}{c}0.000 \\
(0.000)\end{array}$ & $\begin{array}{l}0.000 \\
(0.000)\end{array}$ & $\begin{array}{l}0.000 \\
(0.000)\end{array}$ & $\begin{array}{l}0.000 \\
(0.000)\end{array}$ & $\begin{array}{c}0.000 \\
(0.000)\end{array}$ \\
\hline Size & $\begin{array}{c}-0.022^{* * *} \\
(0.003)\end{array}$ & $\begin{array}{c}0.023^{* *} \\
(0.010)\end{array}$ & $\begin{array}{c}0.0242^{* *} \\
(0.010)\end{array}$ & $\begin{array}{c}-0.008^{* * *} \\
(0.003)\end{array}$ & $\begin{array}{l}0.017 \\
(0.016)\end{array}$ & $\begin{array}{l}0.018 \\
(0.016)\end{array}$ \\
\hline Leverage & $\begin{array}{c}-0.129 * * * \\
(0.018)\end{array}$ & $\begin{array}{c}1.012^{* * *} \\
(0.292)\end{array}$ & $\begin{array}{c}1.013^{* * *} \\
(0.292)\end{array}$ & $\begin{array}{c}-0.122^{* * *} \\
(0.025)\end{array}$ & $\begin{array}{l}0.457 \\
(0.483)\end{array}$ & $\begin{array}{l}0.454 \\
(0.479)\end{array}$ \\
\hline Size $*$ Leverage & & $\begin{array}{c}-0.049 * * * \\
(0.013)\end{array}$ & $\begin{array}{c}-0.049 * * * \\
(0.013)\end{array}$ & & $\begin{array}{l}-0.024 \\
(0.021)\end{array}$ & $\begin{array}{l}-0.024 \\
(0.021)\end{array}$ \\
\hline ST Debt Ratio & $\begin{array}{c}-0.054 * * * \\
(0.014)\end{array}$ & $\begin{array}{c}0.702^{* * *} \\
(0.209)\end{array}$ & $\begin{array}{c}0.745^{* * *} \\
(0.217)\end{array}$ & $\begin{array}{c}-0.054 * * * \\
(0.018)\end{array}$ & $\begin{array}{l}0.521 * \\
(0.297)\end{array}$ & $\begin{array}{l}0.576^{*} \\
(0.304)\end{array}$ \\
\hline Size * ST Debt Ratio & & $\begin{array}{c}-0.032 * * * \\
(0.009)\end{array}$ & $\begin{array}{c}-0.034 * * * \\
(0.010)\end{array}$ & & $\begin{array}{r}-0.024^{*} \\
(0.013)\end{array}$ & $\begin{array}{c}-0.027 * * \\
(0.013)\end{array}$ \\
\hline Export/ Sales Ratio & $\begin{array}{c}0.082^{* * *} \\
(0.011)\end{array}$ & $\begin{array}{c}0.075^{* * *} \\
(0.011)\end{array}$ & $\begin{array}{c}0.075^{* * *} \\
(0.011)\end{array}$ & $\begin{array}{l}-0.007 \\
(0.010)\end{array}$ & $\begin{array}{l}-0.009 \\
(0.010)\end{array}$ & $\begin{array}{l}-0.008 \\
(0.010)\end{array}$ \\
\hline Foreign Debt Ratio & $\begin{array}{c}0.090^{* * *} \\
(0.030)\end{array}$ & $\begin{array}{l}-0.424 \\
(0.412)\end{array}$ & & $\begin{array}{l}-0.033 \\
(0.037)\end{array}$ & $\begin{array}{l}0.018 \\
(0.453)\end{array}$ & \\
\hline Size * Foreign Debt Ratio & & $\begin{array}{l}0.021 \\
(0.017)\end{array}$ & & & $\begin{array}{l}-0.002 \\
(0.018)\end{array}$ & \\
\hline ST Foreign Debt Ratio & & & $\begin{array}{l}-1.032^{*} \\
(0.571)\end{array}$ & & & $\begin{array}{l}0.263 \\
(0.547)\end{array}$ \\
\hline Size $*$ ST Foreign Debt Ratio & & & $\begin{array}{c}0.0465^{*} \\
(0.024)\end{array}$ & & & $\begin{array}{l}-0.009 \\
(0.023)\end{array}$ \\
\hline LT Foreign Debt Ratio & & & $\begin{array}{l}0.159 \\
(0.660)\end{array}$ & & & $\begin{array}{l}0.141 \\
(0.674)\end{array}$ \\
\hline Size * LT Foreign Debt Ratio & & & $\begin{array}{l}-0.004 \\
(0.028)\end{array}$ & & & $\begin{array}{l}-0.010 \\
(0.028)\end{array}$ \\
\hline Observations & 4285 & 4285 & 4285 & 3151 & 3151 & 3151 \\
\hline R-squared & 0.132 & 0.145 & 0.145 & 0.12 & 0.125 & 0.126 \\
\hline
\end{tabular}

Note: The dependent variable is firm profits in 1998 as a share of sales in 1997 for the crisis regressions and firm profits in 1996 as a share of sales in 1995 for the pre-crisis regressions. The independent variables are for year 1996 in the crisis regressions and for year 1994 in the pre-crisis regressions. Robust standard errors are reported in parentheses. *** denotes a p-value less than $1 \%$, ${ }^{* *}$ denotes a p-value less than $5 \%$, and $*$ denotes a p-value less than $10 \%$. All regressions include industry dummies at the two-digit level. 


\section{Table A3: Investment Regressions for Publicly-listed Firms}

\begin{tabular}{|c|c|c|c|c|c|c|}
\hline \multirow{2}{*}{$\begin{array}{l}\text { Dependent Variable } \\
\mathrm{I} / \mathrm{K}_{-1}\end{array}$} & \multicolumn{3}{|c|}{ Crisis } & \multicolumn{3}{|c|}{ Pre-Crisis } \\
\hline & 1 & 2 & 3 & 1 & 2 & 3 \\
\hline Chaebol Dummy & $\begin{array}{l}0.051 \\
(0.045)\end{array}$ & $\begin{array}{l}0.052 \\
(0.045)\end{array}$ & $\begin{array}{l}0.052 \\
(0.045)\end{array}$ & $\begin{array}{c}0.190 * * * \\
(0.068)\end{array}$ & $\begin{array}{c}0.193 * * * \\
(0.069)\end{array}$ & $\begin{array}{c}0.190 * * * \\
(0.070)\end{array}$ \\
\hline Age & $\begin{array}{l}-0.001 \\
(0.001)\end{array}$ & $\begin{array}{l}-0.001 \\
(0.001)\end{array}$ & $\begin{array}{l}-0.001 \\
(0.001)\end{array}$ & $\begin{array}{c}-0.003^{* * *} \\
(0.001)\end{array}$ & $\begin{array}{c}-0.003 * * * \\
(0.001)\end{array}$ & $\begin{array}{c}-0.003 * * * \\
(0.001)\end{array}$ \\
\hline Size & $\begin{array}{l}-0.008 \\
(0.011)\end{array}$ & $\begin{array}{l}0.079 \\
(0.051)\end{array}$ & $\begin{array}{l}0.080 \\
(0.051)\end{array}$ & $\begin{array}{l}-0.008 \\
(0.015)\end{array}$ & $\begin{array}{l}0.027 \\
(0.035)\end{array}$ & $\begin{array}{l}0.027 \\
(0.035)\end{array}$ \\
\hline Leverage & $\begin{array}{l}0.007 \\
(0.086)\end{array}$ & $\begin{array}{l}2.947 * \\
(1.649)\end{array}$ & $\begin{array}{l}2.958^{*} \\
(1.655)\end{array}$ & $\begin{array}{l}-0.050 \\
(0.035)\end{array}$ & $\begin{array}{l}1.528^{*} \\
(0.893)\end{array}$ & $\begin{array}{l}1.542^{*} \\
(0.906)\end{array}$ \\
\hline Size * Leverage & & $\begin{array}{c}-0.121 * \\
(0.067)\end{array}$ & $\begin{array}{c}-0.122 * \\
(0.067)\end{array}$ & & $\begin{array}{c}-0.065^{*} \\
(0.036)\end{array}$ & $\begin{array}{c}-0.065^{*} \\
(0.037)\end{array}$ \\
\hline ST Debt Ratio & $\begin{array}{l}0.023 \\
(0.075)\end{array}$ & $\begin{array}{l}-0.414 \\
(1.192)\end{array}$ & $\begin{array}{l}-0.388 \\
(1.282)\end{array}$ & $\begin{array}{l}0.037 \\
(0.085)\end{array}$ & $\begin{array}{l}-0.274 \\
(1.391)\end{array}$ & $\begin{array}{l}-0.270 \\
(1.532)\end{array}$ \\
\hline Size * ST Debt Ratio & & $\begin{array}{c}0.019 \\
(0.049)\end{array}$ & $\begin{array}{c}0.018 \\
(0.053)\end{array}$ & & $\begin{array}{c}0.012 \\
(0.057)\end{array}$ & $\begin{array}{c}0.011 \\
(0.063)\end{array}$ \\
\hline Export/ Sales Ratio & $\begin{array}{l}0.076 \\
(0.058)\end{array}$ & $\begin{array}{l}0.057 \\
(0.045)\end{array}$ & $\begin{array}{l}0.056 \\
(0.046)\end{array}$ & $\begin{array}{l}-0.077 \\
(0.066)\end{array}$ & $\begin{array}{l}-0.075 \\
(0.067)\end{array}$ & $\begin{array}{l}-0.068 \\
(0.067)\end{array}$ \\
\hline Foreign Debt Ratio & $\begin{array}{l}-0.146 \\
(0.096)\end{array}$ & $\begin{array}{l}-0.760 \\
(1.543)\end{array}$ & & $\begin{array}{l}0.083 \\
(0.173)\end{array}$ & $\begin{array}{l}-2.355 \\
(1.928)\end{array}$ & \\
\hline Size $*$ Foreign Debt Ratio & & $\begin{array}{l}0.024 \\
(0.062)\end{array}$ & & & $\begin{array}{l}0.098 \\
(0.078)\end{array}$ & \\
\hline ST Foreign Debt Ratio & & & $\begin{array}{l}-1.255 \\
(2.030)\end{array}$ & & & $\begin{array}{l}-0.457 \\
(3.250)\end{array}$ \\
\hline Size * ST Foreign Debt Ratio & & & $\begin{array}{l}0.042 \\
(0.083)\end{array}$ & & & $\begin{array}{l}0.032 \\
(0.130)\end{array}$ \\
\hline LT Foreign Debt Ratio & & & $\begin{array}{l}-0.371 \\
(2.912)\end{array}$ & & & $\begin{array}{l}-3.777 \\
(2.884)\end{array}$ \\
\hline Size * LT Foreign Debt Ratio & & & $\begin{array}{c}0.010 \\
(0.118)\end{array}$ & & & $\begin{array}{c}0.144 \\
(0.117)\end{array}$ \\
\hline Lagged I/K-1 & $\begin{array}{c}0.081 * * * \\
(0.031)\end{array}$ & $\begin{array}{c}0.076^{* *} \\
(0.031)\end{array}$ & $\begin{array}{c}0.076^{* *} \\
(0.031)\end{array}$ & $\begin{array}{c}0.175^{* * *} \\
(0.047)\end{array}$ & $\begin{array}{c}0.167 * * * \\
(0.047)\end{array}$ & $\begin{array}{c}0.167 * * * \\
(0.048)\end{array}$ \\
\hline $\begin{array}{l}\text { Observations } \\
\text { R-squared }\end{array}$ & $\begin{array}{c}949 \\
0.067\end{array}$ & $\begin{array}{c}949 \\
0.085\end{array}$ & $\begin{array}{c}949 \\
0.086\end{array}$ & $\begin{array}{c}864 \\
0.185\end{array}$ & $\begin{array}{c}864 \\
0.189\end{array}$ & $\begin{array}{c}864 \\
0.191\end{array}$ \\
\hline
\end{tabular}

Note: The dependent variable is firm real investment in 1998 as a share of the replacement value of real capital stock in 1997 for the crisis regressions and firm real investment in 1996 as a share of the replacement value of real capital stock in 1995 for the pre-crisis regressions. The independent variables are for year 1996 in the crisis regressions and for year 1994 in the pre-crisis regressions. Robust standard errors are reported in parentheses. *** denotes a p-value less than $1 \%$, ** denotes a p-value less than $5 \%$, and * denotes a p-value less than $10 \%$. All regressions include industry dummies at the two-digit level. 
Table A4: Investment Regressions for the Full Sample

\begin{tabular}{|c|c|c|c|c|c|c|}
\hline \multirow{2}{*}{$\begin{array}{l}\text { Dependent Variable } \\
\mathrm{I} / \mathrm{K}_{-1}\end{array}$} & \multicolumn{3}{|c|}{ Crisis } & \multicolumn{3}{|c|}{ Pre-Crisis } \\
\hline & 1 & 2 & 3 & 1 & 2 & 3 \\
\hline Chaebol Dummy & $\begin{array}{l}0.056^{*} \\
(0.030)\end{array}$ & $\begin{array}{l}0.048 \\
(0.031)\end{array}$ & $\begin{array}{l}0.049 \\
(0.031)\end{array}$ & $\begin{array}{c}0.182^{* * *} \\
(0.038)\end{array}$ & $\begin{array}{c}0.175^{* * *} \\
(0.038)\end{array}$ & $\begin{array}{c}0.174 * * * \\
(0.038)\end{array}$ \\
\hline Age & $\begin{array}{l}0.000 \\
(0.001)\end{array}$ & $\begin{array}{l}0.000 \\
(0.001)\end{array}$ & $\begin{array}{l}0.000 \\
(0.001)\end{array}$ & $\begin{array}{c}-0.002 * * * \\
(0.001)\end{array}$ & $\begin{array}{c}-0.002^{* * *} \\
(0.001)\end{array}$ & $\begin{array}{c}-0.002 * * * \\
(0.001)\end{array}$ \\
\hline Size & $\begin{array}{c}-0.015^{* *} \\
(0.006)\end{array}$ & $\begin{array}{l}-0.013 \\
(0.023)\end{array}$ & $\begin{array}{l}-0.013 \\
(0.024)\end{array}$ & $\begin{array}{c}-0.023 * * * \\
(0.008)\end{array}$ & $\begin{array}{l}-0.007 \\
(0.023)\end{array}$ & $\begin{array}{l}-0.006 \\
(0.023)\end{array}$ \\
\hline Leverage & $\begin{array}{l}0.018 \\
(0.029)\end{array}$ & $\begin{array}{c}0.567 \\
(0.710)\end{array}$ & $\begin{array}{l}0.564 \\
(0.710)\end{array}$ & $\begin{array}{l}-0.034 \\
(0.035)\end{array}$ & $\begin{array}{l}1.344 * * \\
(0.628)\end{array}$ & $\begin{array}{c}1.345^{* *} \\
(0.633)\end{array}$ \\
\hline Size * Leverage & & $\begin{array}{l}-0.023 \\
(0.030)\end{array}$ & $\begin{array}{l}-0.023 \\
(0.030)\end{array}$ & & $\begin{array}{c}-0.058^{* *} \\
(0.026)\end{array}$ & $\begin{array}{c}-0.058^{* *} \\
(0.026)\end{array}$ \\
\hline ST Debt Ratio & $\begin{array}{l}-0.018 \\
(0.035)\end{array}$ & $\begin{array}{l}-1.041 \\
(0.705)\end{array}$ & $\begin{array}{l}-1.048 \\
(0.730)\end{array}$ & $\begin{array}{l}-0.038 \\
(0.044)\end{array}$ & $\begin{array}{l}-1.662 * \\
(0.959)\end{array}$ & $\begin{array}{l}-1.593 \\
(1.010)\end{array}$ \\
\hline Size * ST Debt Ratio & & $\begin{array}{c}0.044 \\
(0.030)\end{array}$ & $\begin{array}{l}0.044 \\
(0.031)\end{array}$ & & $\begin{array}{c}0.0689^{*} \\
(0.041)\end{array}$ & $\begin{array}{l}0.065 \\
(0.043)\end{array}$ \\
\hline Export/ Sales Ratio & $\begin{array}{l}0.072^{*} \\
(0.039)\end{array}$ & $\begin{array}{l}0.070^{*} \\
(0.038)\end{array}$ & $\begin{array}{l}0.070^{*} \\
(0.038)\end{array}$ & $\begin{array}{l}-0.009 \\
(0.035)\end{array}$ & $\begin{array}{l}-0.006 \\
(0.035)\end{array}$ & $\begin{array}{l}-0.004 \\
(0.035)\end{array}$ \\
\hline Foreign Debt Ratio & $\begin{array}{l}0.032 \\
(0.075)\end{array}$ & $\begin{array}{l}-2.185^{*} \\
(1.287)\end{array}$ & & $\begin{array}{l}-0.067 \\
(0.091)\end{array}$ & $\begin{array}{c}-4.308^{* * *} \\
(1.330)\end{array}$ & \\
\hline Size * Foreign Debt Ratio & & $\begin{array}{l}0.092^{*} \\
(0.054)\end{array}$ & & & $\begin{array}{c}0.175^{* * *} \\
(0.055)\end{array}$ & \\
\hline ST Foreign Debt Ratio & & & $\begin{array}{l}-1.552 \\
(2.341)\end{array}$ & & & $\begin{array}{l}-2.763 \\
(2.789)\end{array}$ \\
\hline Size * ST Foreign Debt Ratio & & & $\begin{array}{l}0.067 \\
(0.096)\end{array}$ & & & $\begin{array}{l}0.122 \\
(0.115)\end{array}$ \\
\hline LT Foreign Debt Ratio & & & $\begin{array}{l}-2.633 \\
(1.868)\end{array}$ & & & $\begin{array}{c}-4.903 * * \\
(1.977)\end{array}$ \\
\hline Size * LT Foreign Debt Ratio & & & $\begin{array}{l}0.109 \\
(0.079)\end{array}$ & & & $\begin{array}{c}0.193 * * \\
(0.082)\end{array}$ \\
\hline Lagged I/K 1 & $\begin{array}{c}0.088^{* * *} \\
(0.019)\end{array}$ & $\begin{array}{c}0.088^{* * *} \\
(0.019)\end{array}$ & $\begin{array}{c}0.088^{* * *} \\
(0.019)\end{array}$ & $\begin{array}{c}0.164 * * * \\
(0.027)\end{array}$ & $\begin{array}{c}0.161^{* * *} \\
(0.027)\end{array}$ & $\begin{array}{c}0.161 * * * \\
(0.027)\end{array}$ \\
\hline Observations & 4072 & 4072 & 4072 & 2970 & 2970 & 2970 \\
\hline R-squared & 0.043 & 0.046 & 0.046 & 0.097 & 0.102 & 0.103 \\
\hline
\end{tabular}

Note: The dependent variable is firm real investment in 1998 as a share of the replacement value of real capital stock in 1997 for the crisis regressions and firm real investment in 1996 as a share of the replacement value of real capital stock in 1995 for the pre-crisis regressions. The independent variables are for year 1996 in the crisis regressions and for year 1994 in the pre-crisis regressions. Robust standard errors are reported in parentheses. *** denotes a p-value less than $1 \%$, ** denotes a p-value less than $5 \%$, and * denotes a p-value less than $10 \%$. All regressions include industry dummies at the two-digit level. 